\title{
Camphill Contexts
}

A communal movement, like any living thing, evolves in complex relationship with its environment. In the beginning, the relevant environment is small. The movement's growth is shaped primarily by the founders' creativity and strength of will, their capacity to get along with one another, and other internal factors. Movements that reach a second or third generation do so because their founders manage to open themselves to the surrounding world, at least to the extent of welcoming a new generation into movement leadership. This is what Camphill accomplished, rather splendidly, with the incorporation of baby boomers in the 1970 . By the time a communal movement reaches maturity, however, it does not simply live within an environment. It relates simultaneously to multiple contexts, each offering its own challenges and opportunities to the movement. The task of a mature movement is to allow itself to be transformed by each of its contexts, and simultaneously to transform each context by bringing to it distinctly communal practices and ideals.

\section{THE ANTHROPOSOPHICAL MOVEMENT}

Camphill's first context was the anthroposophical movement, and anthroposophy continues to exert a formative influence over Camphill's development. The founders of Camphill began as members of anthroposophical youth groups in Vienna. Like other clusters of younger anthroposophists in the 1920 and 1930s, they were impatient with abstract study and eager to translate their spiritual ideals into concrete practices. When the rise of Hitler forced them out of Vienna, they followed the migration patterns of anthroposophists before and since-to the British Isles, and soon thereafter to the United States, South Africa, Holland, and Scandinavia. Camphill has often planted itself in neighborhoods that were already home to multiple anthroposophical initiatives: the three Camphill places in Pennsylvania, for example, are located on or within a few miles of the estate of Alarik and Mabel 
Pew Myrin, who had begun promoting biodynamics and Waldorf education in that area in 1941. In other places, such as Columbia County in New York, Camphill has been the anchor that has drawn other initiatives to an area. More than any other initiative rooted in anthroposophy, Camphill holds anthroposophy's diverse impulses in a creative synthesis. It has never been satisfied merely to implement the indications Steiner gave in his course on curative education: it has also sought to cultivate biodynamic farms, share in the festivals and liturgies of the Christian Community, provide Waldorf education for children with and without disabilities, offer therapies rooted in anthroposophical medicine, practice eurythmy and other anthroposophical arts, and develop economic and social practices in accordance with Steiner's ideas about the threefold social order.

Rudolf Steiner's indications about how to work therapeutically with persons with intellectual disabilities provide a central point of contact between Camphill and anthroposophy. Steiner's curative education course continues to inspire Camphillers to work holistically for the empowerment of all people regardless of ability. Camphillers echo Steiner when they talk about seeing "the spiritual image of man behind every human being, especially those whose outward appearance or behavior was the most disturbed." Steiner's teaching about karma and reincarnation also motivates many anthroposophists to commit their lives to work with persons with disabilities. This connection is somewhat fraught: from the outside, it might appear that believers in karma would interpret disability as a punishment for the sins of past lives. This is not the anthroposophical view; it is not expressed in the curative education course, and I have never heard it hinted at by anyone associated with Camphill. Camphillers who are committed to anthroposophy will, on the other hand, typically say two other things: first, that human souls incarnate in disabled bodies to achieve specific purposes rooted in their karmic histories; second, that every human being has a dignity and integrity that transcends any particular incarnation.

Camphillers differ on how exactly to apply the idea that disability has a karmically rooted history. Is it enough simply to know that this is the case in general, or ought one to seek insight into the specific purposes underlying the disabilities of specific persons? As part of his esoteric teaching, Rudolf Steiner frequently gave his students insights into how their current incarnations had been shaped by their karmic histories. But anthroposophists have not always agreed on the capacities of people other than Steiner to engage in this sort of karmic research, or on whether it is appropriate to engage in such reflection about anyone other than oneself. Karl König, like his mentor Ita Wegman, was one of those who did share the fruits of his own spiritual research, and whose authority to do so was questioned by other anthroposophists. To some extent, the "college meetings" that he identified as one of the essential elements of Camphill were sites of karmic research. Coworkers gathered to reflect intensively on the whole person of one of their students-the child's parents, biography, symptoms, astrological chart, and much more-and in 
this context König would share insights into the child's karma. But Camphillers who were active in the movement during König's lifetime have different memories about the degree of emphasis on karma in college meetings. And few if any subsequent Camphillers have claimed capacities comparable to König's or Steiner's. The college meeting lost much of its centrality with the rise of Camphill villages and other adult communities, since all agree that it is inappropriate to reflect on the karmic history of an adult without that person's active participation.

When I have heard Camphillers talk about karmic history and disability, it is often in general terms: Jens-Peter Linde, for example, told me that "when in Hitler's Germany lots of disabled people were actually killed, they could inspire young people from the spiritual world to actually come find Camphill." This, in turn, helped bring about changes in public policy guaranteeing the rights of persons with disabilities. ${ }^{2}$ Many Camphill coworkers are more comfortable talking about their own karmic histories than those of the people with whom they live, and they also apply other spiritual concepts to make sense of their Camphill experiences. Several people told me that working with persons with disabilities has given them the chance to "experience the lesser guardian of the threshold"-a frightening spiritual being who confronts and challenges a person rising to a higher level of spiritual maturity, enabling the person to work more freely and consciously with their karma. "When you live in these multiplex communities and have relationships with people," one Camphiller explained, referring not only to persons with disabilities but to everyone living in lifesharing community, "they will form a mirror in which you see reflected from them your lesser guardian." He went on to challenge König's spiritual interpretation of disability, which, he said, encouraged benevolent paternalism by portraying all people with Down syndrome as unconditionally loving but weak in their egos. "I've lived with such people," but "people are far more complicated now." Many younger people with Down syndrome also have "autism, challenging behaviors, precocious sexuality." But he still insisted that the basic karmic task was "to recognize the biography of the people we are funded to look after" - to recognize "what their task is" and "give them opportunities, stretch them, give them challenges." And he fully endorsed the "fundamental principle of Camphill" that "the adult with learning disabilities is my teacher."

More frequently, I have heard Camphillers simply state that Steiner's teaching on karma and reincarnation helps them see the human dignity present in even the most profoundly disabled person. One person who had worked at Garvald told me, "From the perspective of reincarnation as Steiner described it, some people with learning disabilities in a previous life, might not have had learning disabilities, and we ourselves possibly might have learning disabilities in our next earthly life. . . . Steiner gave the picture of the violin with a broken string. People with learning disabilities could be viewed like the violin: they are wholly there, but with a broken string which affects how they play their whole tune. It might be something physical such as brain damage, but behind that person is a fully intact per- 
son. So that is really who you should be speaking to, the full person, with nothing but respect for that individual." 5 This approach contrasts with that of many mainline Christians who believe that each person has a single unique incarnation: for these Christians, a disability may be an integral part of someone's wholeness, not a broken string at all. In practice, though, the resulting ethos of respect for human dignity is much the same.

Steiner provided Camphill's founders not only with a method for developing the potential of persons with learning difficulties but also with a rationale for organizing on a cooperative, communal basis. Steiner laid a foundation for lifesharing in his stress on the healing potential of person-to-person encounters; he laid a foundation for incomesharing in his critique of wage labor, which he saw as inimical to human dignity because it treated people as commodities. Camphillers also draw deeply on one of Steiner's economic teachings, which he referred to as the "Fundamental Social Law." According to this "law," the well-being of any community will be enhanced "the less the individual claims for himself the proceeds of the work he has himself done" and "the more his own requirements are satisfied not out of his own work done, but out of work done by the others." ${ }^{3}$ Many Camphillers see this "law" as the heart of Steiner's social teaching, and they often say that the possibility of working out of love rather than for the sake of money was a major factor drawing them to the movement.

Yet Camphill's relationship with the anthroposophical movement-and, especially, with the Anthroposophical Society-has always been complex. None of Camphill's founders knew Rudolf Steiner personally, though a few of those who arrived at Camphill in the 1940s did. None of the other major initiatives rooted in anthroposophy received so little direct shaping from Steiner-unless one includes new impulses that emerged decades after Camphill, such as anthroposophical banking.

Because Karl König had an especially close connection to the Christian Community (the specifically religious expression of anthroposophy, which is structured as a small denomination with a distinctive liturgy), he forged a special relationship between Camphill and the Christian Community. In 1942 he and the leader of the Christian Community in Great Britain signed a formal agreement that Camphill would celebrate the sacraments of the Christian Community, which in turn would recognize Camphill as a sister community rather than one of its congregations. But this arrangement brought its own difficulties, and it was eventually annulled because it had never been ratified by the Christian Community's international leadership. Several Camphillers received ordination in the Christian Community, and the sacraments continued to be observed faithfully, but there was a "mutual reserve" between the two movements until 1973, when a series of gatherings were convened to bring them back into accord. ${ }^{7}$

Most Camphillers of the first and second generations learned their anthroposophy primarily from Karl König. Like his teacher Ita Wegman, König was a 
charismatic leader who freely shared the fruits of his spiritual research with his followers. No other anthroposophist has attracted as much ongoing study and devotion as König - evident, for example, in the publication of most of his writings by the Karl König Institute. One consequence of König's powerful personality is that many of the practices by which Camphill has remained connected to anthroposophy - and by which Camphillers measure the degree of their adherence to anthroposophy - are the distinctive fruits of König's spiritual striving, and are not practiced outside of Camphill. These include the Camphill inner community, the Bible Evening, and the practice of incomesharing, which Camphillers but not most other anthroposophists regard as mandated by Steiner's Fundamental Social Law.

Currently, the inner community, Bible Evening, and incomesharing are all in decline within the Camphill Movement: vital in a handful of places, struggling to survive in many more, and entirely absent in the rest. Many of the Camphillers I interviewed were thinking of this reality when they identified the declining centrality of anthroposophy as the most significant challenge facing the movement. Some, such as Jonas Hellbrandt, also observed that fewer Camphillers embrace anthroposophy "as an overarching kind of philosophy," even if they continue to apply anthroposophical insights to particular tasks or practices. ${ }^{8}$ Another coworker, Angelika Monteux, worried that others felt it was enough simply to uphold "the Camphill ethos and the Camphill ways," without reference to anthroposophy. Her response was to ask, "but where do the Camphill ways come from?"9

Yet few imagine that simply restoring the practices of Camphill's past would be an adequate solution. Steiner always understood anthroposophical initiatives as gifts from anthroposophy to the world, not as strategies for promoting anthroposophy directly, and in keeping with this mindset, everyone agrees that Camphills must remain pluralistic communities in which people of diverse spiritual paths are free to participate. Anthroposophy, moreover, is an evolutionary worldview, and so everyone agrees (at least in principle) that its appropriate expression in the twenty-first century will look different than in the twentieth. Many Camphillers express their vision for the future of anthroposophy in Camphill in surprisingly general terms. "The whole view of anthroposophy is to help us become more truly human, more truly who we are," one person told me. "If that can happen, then somewhere anthroposophy is alive." ${ }^{10}$ Another insisted that anthroposophy was not "a religion" or "the answer", but rather "something which adds on to most areas of life, and can give you a totally different way into something" because of its "inherent openness and curiosity and wish to look for meaning and truth." ${ }_{11}$

Typically, Camphillers who would like to strengthen anthroposophy in their movement are more critical of themselves, and of others committed to anthroposophy, than they are of the Camphillers who find little meaning in it. Javier Gonzalez Roa, a young employee with a deep connection to anthroposophy, emphasized that a special kind of person is needed to convey anthroposophy in an age that doesn't think it needs spirituality at all. "You can't feed a baby with meat," he said, alluding to a workshop that he found amazing but that turned off most 
of its audience with lots of "talk about demons and angels." A better approach is "to find the subject these people are going to be interested in, such as biodynamics or art or philosophy of freedom. You have thousands of ways to connect with people."12 Ruairidh von Stein, who insisted that anthroposophy was both the "anchor" and the "heart" of Camphill, also emphasized that "there are also other spiritual streams that we are working together with in brotherliness." For him, preserving Camphill's deep connection to anthroposophy was a personal task more than a demand to be placed on others. "I don't mind if there aren't many people who study it. I will carry it and share it in my own way through my meditation work, sending people thoughts, working with the warmth bodies around them.... Because we have to help each other. . . It is really important that anthroposophy lives." 13 This sentiment was echoed by a Camphiller who expressed many seemingly hopeless thoughts about anthroposophy in a hopeful voice. When I asked him to explain this contradiction, he mused. "It is individuals. Why am I here? Because of an individual. It is not because of an organization. Individual enthusiasm, individual interest. So my hopefulness comes from that."14

Many Camphill places today are experimenting with new structures for keeping anthroposophy alive in the movement. Around 2011, the Camphills near Aberdeen created two new groups for persons who were curious about anthroposophy. The Aberdeen Circle was designed, said Marjan Sikkel, as "a very intensive study group where we really try to do the exercises in How to Know Higher Worlds." ${ }^{15}$ In some ways, this group reflects a long-standing concern that existing anthroposophical study groups emphasize intellectual engagement with Steiner's writings at the expense of meditative practice; its agenda runs parallel to anthroposophical impulses beyond Camphill, such as the Goetheanum Meditation Initiative and Arthur Zajonc's work promoting meditative practice. ${ }^{16}$ This group is not exclusively for members of the Anthroposophical Society or the Camphill inner community, yet in practice most of its members are older coworkers also involved in those groups. Another new group works specifically with younger Camphillers, and much of its emphasis is simply on "the social aspect of it"-giving younger people a chance to engage with anthroposophy in a space that is not dominated by the older generation. ${ }^{17}$

Camphill's grappling with the place of anthroposophy often focuses on an essay by Karl König that identified "three pillars" of Camphill. These are the college meeting (a practice of reflection on individual students that is only practiced in Camphill schools); the Bible Evening (a weekly ritual of Bible reading, meditation, and conversation); and the Fundamental Social Law, which is the basis for Camphill's practice of incomesharing. By the turn of the twenty-first century, it was commonplace in Camphill publications for writers to state as uncontroversial fact that "all three pillars of Camphill are in serious trouble."18

The Bible Evening is a ritual in which Camphillers gather, on Saturday evenings, to reflect together on a Gospel text that they have been reading each day for the previous week. It begins with an extended period of silence, sometimes as much 
as fifteen minutes. This is followed by the reading of an anthroposophical verse, conversation about the week's events, and conversation about the week's text. The Bible Evening prepares its participants for the Sunday morning liturgy. Most commonly, that liturgy is the Festival of Offering (Opferfeier), a lay service that Rudolf Steiner created for teachers to use with their students in the Waldorf school movement. Karl König's early hope was that Camphill schools would use this service while Camphill villages would celebrate the Act of Consecration of Man, which requires the presence of a Christian Community priest. Because most villages lack a resident priest, they tend to use the Festival of Offering. ${ }^{19}$ The Bible Evening also prepares participants for the intervening night. An essential aspect of anthroposophical meditative practice is the notion that the spiritual work one begins during one's waking hours will continue in a different way during sleep. Participants in a Bible Evening often experience new insights on the morning that follows.

In the Camphill Movement today, the Bible Evening is a primary marker of whether a particular Camphill place is still vitally connected to anthroposophy. It is most typically practiced in individual houses, after a festive "Bible Supper." Since most Camphills serve their main meal at noontime and offer simple "breads and spreads" at the end of the day, just a few more indulgent spreads or a soup can suffice to distinguish "Bible Supper" from other evening meals. Especially in the larger Camphill places, some houses celebrate Bible Evening more frequently than others, but in general it is rare for any house to celebrate it every week and common for some houses (or entire communities) to have dispensed with it altogether. Those houses where baby boomer coworkers and/or inner community members are present are much more likely to observe Bible Evening than other houses. Indeed, many Gen-X and millennial house coordinators say that the reason they don't celebrate Bible Evening is because they don't know how to do it correctly. Some communities have addressed this issue by celebrating a single, occasional rather than weekly, Bible Evening for the entire community.

The fact that some Camphillers today observe Bible Evening while others do not is a faint echo of the early years of the movement, when Bible Evening was observed exclusively by members of the inner community. After Karl König established the Bible Evening on August 30, 1941, his companions experienced the new ritual as powerful and unnerving. It was the culmination of each week's work, both of the practical labors of the days and the spiritual study of the evenings. Things began, explains Angelika Monteux, with "a Bible Supper on Saturday with the pupils. ... They got all [dressed] nice . . . and the gospel was read, creating a nice peaceful atmosphere. Then the children went to bed, and the coworkers had the Bible Evening." ${ }^{20}$

The Bible Evening was observed exclusively by the inner community until König's "Third Memorandum" opened it up to other Camphillers. The inner community understood this as the final stage of a threefold sacrifice: first they had given up control of Camphill's economic life, then of its governance, and finally of 
its free spiritual life. They hoped that this would enable the Bible Evening to help new social forms germinate beyond Camphill, but they also anticipated accurately that "the Bible Evening will have to wander into the World, through valleys and heights, through the days and nights of human existence, through loneliness and distress, through joy and sorrow." ${ }^{21}$ Near the end of his life, Karl König offered further guidance in a "Bible Evening Memorandum" that underscored its esoteric continuity with the spirituality of the Moravians, Rosicrucians, and Templars. He affirmed emphatically that the Bible Evening was "a direct continuation of what lived among the Bohemian Brotherhood." "The waiting in silence and the opening verse stand under the sign of the Rose Cross," he wrote, while the meal and conversation prepare a "vessel" for the Gospel reading, allowing a "Grail Act" to "be fulfilled." König also anticipated the ongoing evolution of the ritual, for "what until now has only been partially realized is the metamorphosis of the Bible Evening from a tradition-bound Gabrielic form into a new Michaelic form." ${ }^{22}$

The Bible Evening continues to be cherished by many Camphillers of the baby boom generation, coworkers and villagers alike, for whom it retains an aura of esoteric sacrality. When a film was made about Camphill Vidaråsen in the 197os, for example, the Camphillers agonized over whether to allow the filmmakers to film the Bible Evening and decided to do so in part because one of Camphill's founders, Peter Roth, expressed approval of the idea. ${ }^{23}$ Another long-time coworker recalled that when he started in Beaver Run, Bible Evening was very strong and as a consequence, "the life in the homes was very rhythmical, very strong." ${ }^{24}$ Yet other baby boomers, and the vast majority of coworkers who arrived after the 1980s, struggle to connect the lived reality of Bible Evening with the vivid picture painted by Camphill's founders. One baby boomer coworker told me that he and his wife lead the only house in their large village that is committed to Bible Evening, and that even for them it is partly a matter of habit. "We have done that as a life pattern for many years now, and we intend to go on doing it." "25 "We talk about the glorious time of the Bible Evening," mused Angelika Monteux, "they weren't always glorious. They could be incredibly boring. Always the same people saying the same things and you sat there and didn't dare to say anything else.... Some people were very, very put off by that. Said it is all fake, and not true, and not alive anymore." ${ }^{26}$

Practical factors have also contributed to the decline of the Bible Evening. When Beaver Run began accepting more day students, for example, they had to shift their traditional "rest day" from Thursday to Saturday. This meant that coworkers as well as students suddenly had a real weekend. Many took the opportunity to travel outside the community, rather than participating in Bible Evening and the service that followed. ${ }^{27}$ Vidaråsen experienced a similar transition when they implemented a policy mandating two free days per week for all coworkers. ${ }^{28}$ Ruairidh von Stein, who grew up as a staff kid at Botton Village and returned there as an adult, told me that the village's increasing prosperity had undermined Bible Evening. "We used to have coffee just on Sundays, not the whole week. ... 
Saturday, the Bible Evening, was a very special moment, and Sunday was a special day. ... On the Bible Evening you are preparing for Sunday. But now on Sunday people are shopping with friends and going to market." ${ }^{29}$

Almost everyone agrees that if the Bible Evening is to have a future in Camphill, it must be transformed, but there is little agreement about what that transformation might entail. In a 2008 special issue of the Correspondence devoted to the Bible Evening, one contributor proposed that a change of name to "Community Evening" or "Biography Evening" would better reflect the current practice of the ritual, then added that "The Quickening" or "The Wellspring" would convey its aspiration in poetic form..$^{3}$ By contrast, a coworker at Heartbeet said that their Bible Suppers, though held only every few months, were characterized by "rambunctious debates about the Bible readings and what they could possibly mean." Precisely because Heartbeet was such a young community, she added, it could conduct Bible Suppers in a manner that signaled that "we struggle with this too, and we are figuring out what anthroposophy actually means, and it doesn't just have one answer, and we want to explore that with you." ${ }^{31}$ A similar sentiment was expressed by Steffi Hagedorn, a millennial generation coworker at Solborg who told me that "I'm not Christian, but we have Bible Evening. We always have it. I'm strongly into the Camphill Bible Evening." As a young coworker at Solborg she had experienced Bible Evening, but when she left the community and returned a few years later, it had disappeared. When she tried to bring it back, the villagers resisted, so she made it voluntary. "Okay, you can stay in your own room, we will have Bible Evening. And then-some took a week, some took two weeks, but then they were all here. And right now it gives something to the house. Something I really like about Camphill is the effort people make about things that are not technically necessary. We'd be fine without Bible Evening, we'd just watch a movie or go bowling, do something else. But it doesn't demand the kind of effort and it doesn't give back." By contrast, Bible Evening "lifts something ordinary to something special." ${ }^{2}$

When I visited Cairnlee in Scotland, long-term coworkers told me about the process of negotiation in their community. For many years they had practiced a rhythm in which the whole household-students and coworkers-celebrated a Bible Supper together, followed by a late night Community Evening specifically for coworkers. But a newly arrived cluster of houseparents found the every-Saturdaynight rhythm to be restrictive, so they proposed holding Bible Supper fortnightly and moving Community Evening. Coworkers who had been at Cairnlee longer suggested that the decision about Bible Supper belonged to the students, who "were quite clear they wanted to have Bible supper every Saturday." But they agreed to move Community Evening to Mondays. "We've done it for two years and we are getting used to it," one of them reported. "I can accept that it's just not the same thing that it used to be. It's a team-building meeting and it's still a very important part of the week but it is not the realm of the Bible Evening." ${ }_{33}$ 
The sacraments of the Christian Community occupy a place within the Camphill Movement that is similar to that of Bible Evening. Many of the older schools and villages offer either the Festival of Offering or the Act of the Consecration of Man on a weekly basis, often in a chapel built specially for that purpose. In my experience, the most devoted participants in these rituals are villagers, who usually constitute two-thirds of the gathered congregation. Many of the rest are young coworkers who are present merely to assist villagers from their homes. Longterm coworkers of the baby boomer (or previous) generation typically provide ritual leadership, but otherwise are not well represented in the congregation. I have rarely seen more than half of the coworkers whom I know to be deeply connected to anthroposophy attending a service, except during festivals or conferences. Another puzzling aspect of Camphill's religious practice is that villagers and students are not more frequently invited to become service holders or worship assistants, given their obvious commitment. To be sure, I have seen a few in these roles over the years.

Many Camphill places, especially those founded in the 1970s or 1980s, have adopted a mixed rotation of worship experiences. At Camphill Village Minnesota at the turn of the century, the long-term coworkers led the Festival of Offering one Sunday a month, and another Sunday each month there was a spiritually eclectic gathering, with responsibility for the gathering rotating among the houses. On the remaining two Sundays each month, community vans brought villagers and a few coworkers to Protestant and Roman Catholic services in the nearby town. A retired monk who lived a semi-eremitical life near the community's chicken coop provided additional transport for Catholic villagers committed to weekly attendance at the Eucharist. A coworker at Tiphereth, near Edinburgh, described a similar three-week rotation among a gathering, visits to the parish church, and a Christian Community service. The coworker noted that weekly services had both a "social" and a "spiritual aspect, because we are all related to some kind of a spiritual or religious realm of life." Likewise, he said, Tiphereth hosted a Bible Evening one week, "then a social supper, then a festive supper. We have three different qualities. But still again the most important is the social aspect of it." These variations on Camphill tradition were, in his view, the only authentic expression of anthroposophy, because "if you really look through [Steiner's] books, he said, seek and learn and develop and evolve. The last thing he wanted was that this is how it is and stay like that." ${ }^{4}$ Yet another Camphill place alternates religious services with an "ecumenical moment, a little gathering where any topic can come up which has to do with the human being in the more inner qualities." At one such gathering, for example, the Camphillers discussed recent research showing that dying rats have brain patterns similar to those associated with the "near death" experience in human beings. ${ }^{35}$

While Bible Evening and Christian Community rituals are unappealing even to some of the Camphillers who are most deeply connected to anthroposophy, 
the festivals are valued even by many who otherwise feel little connection to the work of Rudolf Steiner. "We celebrate all the Christian festivals, even St. John's and Michaelmas, which nobody else outside of Camphill ever celebrates anymore," explained Jake Vollrath at Newton Dee. "On a practical level they provide good landmarks through the year to help build a routine with the people that we work with. Christmas is obviously during winter, Michaelmas is kind of the start of autumn, Saint John's would be start of summer, Easter the start of spring. So they are quite important landmarks to identify what time of year you are in. But also I like the rituals. . . . And I quite enjoy supporting people who believe in it to take part in it. I quite enjoy taking part in a lot of it myself because I find a lot of beauty in it." But his household never celebrates Bible Evening, in large part because none of the villagers who live there want it. "They like to do Festive Supper, though, on Saturday. So basically instead of Bible Evening we are still having the buns, the tuna spread, the nicer meal, but without the Bible part of it. We still discuss things." 36

Older Camphillers regard the decline of the Bible Evening and Christian Community services with wistful sadness, but rarely with active opposition. From an anthroposophical perspective, the "free spiritual life" must be kept free. If people choose not to participate, there is little to be done directly. Consequently, the struggle over the role of anthroposophy in Camphill more often centers on the practice of incomesharing, and on the text that Camphillers see as the basis for that practice, Rudolf Steiner's Fundamental Social Law. Few texts of Steiner's are cited as frequently in Camphill, and the reason is clear: many Camphillers regard it as a crystallization of a truth that they have experienced personally.

"Egoism has become the force which separates people from people," explained Andrew Plant, a long-time coworker at Camphill Milltown, "and the only way to overcome this is if the individual works freely without expectation of monetary reward to serve either the social group he finds himself in or to serve the other person." ${ }^{37}$ One person said that the Fundamental Social Law made sense to her because she had grown up in Camphill "with the idea of not being salaried and separating work and payment," and consequently "to think of a shared lifestyle and shared resources was always how I wanted to live." ${ }^{38}$ Long-term coworkers with no personal commitment to anthroposophy are often just as enthusiastic about the Fundamental Social Law as those who participate actively in the Anthroposophical Society.

The Fundamental Social Law, articulated in 1906, was an early hint of the more comprehensive social theory, known as "social threefolding," that Rudolf Steiner promoted after World War I. Presented both as a description of the way society is and a prescription of the way it ought to be, social threefolding distinguishes three autonomous spheres: the economic realm, where "brotherliness" or solidarity is the guiding value; the "middle" or "rights" sphere, where equality governs the way people interact with one another; and the spiritual and cultural sphere, where 
perfect freedom reigns. Implicit in this approach is a distinction between work and income. Work, which involves human manipulation of the physical world, is in the economic sphere and therefore people ought to work for the benefit of others to the extent their capacities allow. Income, on the other hand, is in the rights sphere: as equal humans, we all should be guaranteed sufficient income to meet our basic needs. Steiner saw this philosophy as a middle way, neither capitalist nor socialist, and he refrained from direct cooperation with either Marxists or fascists in promoting threefold ideals. Subsequent students of Steiner have forged various political alliances: in the 1930s, many embraced the libertarian right because they opposed state intervention in the economic sphere; in the 1980s, anthroposophists were among the founders of the German Green Party.

Amid the diverse attempts to apply Steiner's social theories in contemporary life, Camphill's practice of incomesharing-in which work is performed by unsalaried volunteers whose needs are met by the community-is relatively unique. Few other anthroposophical initiatives are structured this way. Though many Camphillers regard the Fundamental Social Law as equivalent to Marx's dictum of "from each according to their ability, to each according to their need," this is by no means the only possible interpretation of Steiner's words. The Law resonates almost equally well with Adam Smith's argument for free trade and the division of labor, since both of those practices increase the extent to which any one person will have their needs met by the labor of others. Steiner had a basically positive view of the division of labor: "it precludes egoism," he said, because "one can only work for others, and let others work for oneself." This is not to say that Steiner was a conventional capitalist: he also said that if egoism is "present nevertheless in the form of class privilege," its coexistence with the division of labor will "lead to severe disturbances in the social order." 39

To make sense of the apparent contradiction between Camphill's interpretation of the Fundamental Social Law and that of other anthroposophical initiatives, I took a closer look at the three-part essay in which Steiner first expressed the Law. ${ }^{40}$ Currently, the Fundamental Social Law serves Camphill primarily as a decontextualized proof text; I have rarely heard Camphillers discuss any of the other material found in the essay. It was written before the founding of the Anthroposophical Society and thus has a different context from Steiner's subsequent writings on threefolding. Whereas Steiner developed threefolding in response to the postwar crisis engulfing Europe in 1918 and 1919, in the earlier essay he was concerned with the narrower question of how a spiritual movement (at the time, the Theosophical Society) ought to be engaged with social and economic questions. This gives it special relevance as Camphillers wrestle with their evolving relation to anthroposophy.

The essay, published in the journal Steiner edited on behalf of the Theosophical Society in Germany, was written in response to people who wondered what theosophy, with its commitment to "the highest human ideals," might have to contribute to 
early twentieth-century conversations about social justice. Steiner criticized those who said that theosophy could contribute nothing because of its focus on "the soul's inward life": these critics falsely imagined that theosophy was a collection of doctrines, when in fact it was a set of spiritual disciplines capable of "training the eye for a right conduct of everyday affairs." ${ }^{41} \mathrm{He}$ was even more critical of theosophists themselves for giving fodder to the critics by neglecting "the virtues of neighborly love and human usefulness" in order to "sit aloof, nursing in one's soul the latent seeds of some higher faculty." In any case, Steiner said, the entire debate hinged on whether "one regards the causes of the good and bad in social life as lying rather in men themselves" or in in "the conditions under which men live." Though people of good will took both positions, the former was the correct one, since the conditions that shape human lives have "themselves been created by men." 42

That sounds like a critique of Marxist materialism. Yet Steiner framed his argument in relation not to Marx but to Robert Owen, the nineteenth-century utopian socialist whom Karl König would later honor as one of the guiding "stars" of the Camphill Movement, alongside the Moravian teachers Zinzendorf and Comenius. ${ }^{43}$ Owen was well suited to this role of foil, for his utopian theory centered on the notion that the way to change individuals is to change society. Human nature, Owen believed, is entirely plastic (evidently with no karmic inheritance to work out!), and if humans are placed in a community structured around principles of equality and cooperation, they will naturally become cooperative and equal. Owen was also an appealing foil because he partially recanted the materialist assumptions underlying this theory at the end of his life, when he embraced the spiritualist movement. In Steiner's telling, the failure of Owen's "artificially devised scheme" at New Harmony forced Owen "to the conviction that any good institution is only so far maintainable as the human beings concerned are disposed by their own inner nature to its maintenance and are themselves warmly attached to it." Owen did not think deeply enough about the need to overcome human egoism, and contemporary reformers fell into the same mistake whenever they framed the "social question" as "What particular social institutions must be devised, in order that each person may secure the proceeds of his labor for himself?" It was at this point in the argument that Steiner introduced the Fundamental Social Law, suggesting that it offered an approach to social justice that stepped entirely out of the egoistic framework. The Law, he suggested, would lead to the creation of institutions in which "no one can ever claim the results of his own labor for himself, but that they all, to the last fraction, go wholly to the benefit of the community." By contrast, "he who labors for himself cannot help but gradually fall a victim to egoism." 44

Thus far, Steiner's argument does seem to point toward the creation of incomesharing intentional communities as the best way to institutionalize the Fundamental Social Law. But he then turned the argument in a decidedly anti-institutional direction. It is impossible, he wrote, to articulate a social 
"solution that shall hold good for all time," echoing his observation in an earlier esoteric lesson that "spiritual science has no patent recipe to tell anyone how to act in any specific situation." 45 The specific challenge of our time is to practice the Fundamental Social Law in perfect freedom. Since "compulsion is out of the question" in modernity, "the problem of the present day is how to introduce people into conditions under which each will, of his own inner, private impulse, do the work of the community." The Fundamental Social Law, in short, could triumph only through the accumulation of freely made individual choices: "Wherever this law finds outward expression, wherever anyone is at work along its lines ... there good results will be attained, though it be but in the one single instance and in ever so small a measure. And it is only a number of individual results, attained in this way, that together combine to healthy collective progress throughout the whole body of society." Steiner also insisted that the wellspring of such individual choices would be "a spiritual world-conception" able to "make a living home in the thoughts, in the feelings, in the will-in a man's whole soul." ${ }^{4}$

All of this can read as a critique of Camphill practice, to the extent that Camphill imposes incomesharing on coworkers without waiting for them to develop the "inner, private impulse" needed to choose it freely. Conversely, it could be used to clarify the intent beneath König's own invocation of Owen. Owen's whole life, he said, was a search for the Fundamental Social Law, but he "worked in the dark" because he lacked "the light of true knowledge and wisdom." Camphill's task, from this perspective, might be to continue evolving until it finds a way to practice incomesharing out of inner freedom rather than outer structure. An anecdote from Camphill's early history supports this view. When König asked coworker Morwenna Bucknall to do biographical research on Owen, she objected, asking, "What can he do for us?" König exploded back, "It is not a question of what he can do for $u s$, but of what we can do for him?"47

Steiner himself hinted at the possible existence of communities capable of manifesting in the present a level of cooperation that is mostly part of humanity's evolutionary future. There now exist "definite communities," he claimed, whose work "will make it possible for mankind, by their assistance, to make a leap forward, to accomplish as it were a jump in social evolution." But these communities were veiled in secrecy, as theosophy "does not find itself called upon to discuss these things in public." 48

Perhaps traditional Camphills could be regarded as among these evolutionarily precocious communities that are able to transcend egoism collectively rather than individually. Even if this is so, Steiner's essay makes it abundantly clear that Camphills that abandon incomesharing as a mandatory practice for coworkers need not thereby abandon the Fundamental Social Law as a guiding principle. These Camphills simply find themselves in the same position as other anthroposophical initiatives, and indeed modern humanity as a whole: challenged to help each individual achieve the "spiritual world-conception" that will empower them 
to do the work of the community in freedom. The Camphills that have created incomesharing pools among individuals who receive state-mandated salaries have been wrestling with this challenge for several decades, and the fact that most have struggled to maintain those pools does not necessarily refute Steiner's argument. It simply confirms his claim that the task of embodying the Fundamental Social Law can never be definitely achieved, but must be realized anew by each person in every age. As Camphiller Christoph Hanni put it crisply, "one of my definitions of anthroposophy is, when you don't stop thinking. . . . There is always some further way to go." 49

The demise of traditional incomesharing among coworkers may be an invitation for Camphill to consider what the Fundamental Social Law might mean for all of Camphill's constituencies: for villagers, employees, parents, and board members as well as coworkers. For most of Camphill's history, there has been an implicit assumption that as long as coworkers are practicing incomesharing, then the Fundamental Social Law (and perhaps, by extension, anthroposophy itself) is alive in Camphill. Now that that cannot be assumed, there is new space for other constituencies to embody it in transformative way. In Camphills without lifesharing coworkers, for example, villagers still live cooperatively, work on behalf of one another's needs, and receive income that is proportionate to their human needs rather than to the monetary value of their labor. Many people worry that the traditional Camphill spirit will gradually fade in these places because of the absence of coworkers, but this may reveal a lack of faith in the capacity of persons with learning difficulties to create authentic community, with or without coworkers.

Similarly, as I shall discuss later, the social care bureaucracy is currently calling for more "choice" and "individuation" in the provision of social care, with the implication that individuals with special needs should be able to choose their housing, their therapies, their workplaces, and their cultural activities from a wide menu of choices, rather than making a single comprehensive choice to participate in a holistic community like Camphill. Camphillers often worry that the demand for individuation is an expression of the very egoism that the Fundamental Social Law seeks to overcome. But perhaps it is instead an outgrowth of the modern emphasis on freedom that, according to Steiner, any attempt to realize the Fundamental Social Law must take for granted. If this is so, communities that accept the regime of individuation will in fact give their students and villagers an authentic opportunity to embody the Fundamental Social Law by freely making cooperative rather than egoistic choices. What would happen, coworker Mischa Fekete asked, if "the boundaries of Camphill became so permeable that the people within the community could work elsewhere, could be involved in other social impulses?" The result might be "a certain shrinkage," but it would also strengthen the community because "what is left at the center would be very real and authentic and stand the test of scrutiny." ${ }^{50}$ 
I do not pretend to know the future, and I do not assume that Steiner's account of how best to realize the Fundamental Social Law was correct in every detail. It may be that the "definite communities" of cooperation that Steiner mentioned almost as an afterthought will in fact be the main vehicle through which humanity moves to a cooperative future, and that the free choices of individuals will prove inadequate to the task of overcoming egoism. It may be that people who find themselves, more or less accidentally, in communities that expect everyone to work on behalf of others will gradually acquire the spiritual maturity needed to choose such behavior freely, while those who try to develop sufficient spirituality to make such choices without institutional support will inevitably fail. If these things are true, it would be a very good thing if some Camphill places continue to organize themselves around mandatory practices of incomesharing and lifesharing. But such an outcome would, I think, be a vindication not of Rudolf Steiner's account of social evolution, but of Robert Owen's.

Both incomesharing and the Bible Evening, I have suggested, are the fruit of Karl König's distinct interpretation of anthroposophy. It is possible that both could disappear even as the Camphill Movement deepens its connection to other dimensions of anthroposophy, not filtered through König's unique vision. It is now more possible for Camphill to draw on the resources of the anthroposophical movement as a whole than it was in König's time. The schism that rendered König a spiritual as well as political refugee is a thing of the past. Camphill has been an active participant in the ongoing process of reconciliation. In the 1970s, the Camphill founders each agreed to befriend one member of the society's executive committee, and to encourage younger Camphillers to get more directly involved. ${ }^{51}$ The 1970 youth conference featured a dialogue between Carlo Pietzner, representing Ita Wegman's side of the schism, and Hagen Biesantz (a member of the Anthroposophical Society's executive council) representing the other side. "It was symbolic that these two really came together and were working together," recalled Michael Babitch, and even though he didn't quite grasp the significance at the time, it instilled in him a keen sense of the spiritual power underlying Camphill. ${ }^{52}$ In recent years, the Anthroposophical Society's executive committee has included several persons whose heritage ties them to the excluded groups. Cornelius Pietzner, son of Carlo and Ursel Pietzner and himself a cofounder of Camphill Soltane in Pennsylvania, served as the executive committee's treasurer from 2002 to 2011. Karl König's granddaughter Joan Sleigh, who grew up in the Camphill communities of South Africa, joined the executive committee in 2013. The 1979 establishment of an ongoing Conference of Curative Education, Social Therapy, and Social Work, as part of the School of Spiritual Science and with full participation of Camphillers, was another milestone. Camphill Academy founder Jan Göschel is one of the leaders of this body, now called the Anthroposophic Council for Inclusive Social Development, and Camphiller Rüdiger Grimm was one of his predecessors in that role. 
Camphill and the Goetheanum also cosponsored a 2009 conference, in Dornach, on the theme of community building. ${ }^{53}$

Still, the old tensions between Camphill and the Anthroposophical Society have not disappeared altogether. "Many anthroposophists find Camphill odd," one person told me. "It is like a breed of its own." 54 Another reported that he "was almost a pariah" when he attended a conference on anthroposophical work with people with disabilities where he was the only Camphiller. The others, he said, had an image of Camphill as a place that was "still depriving individuals of certain basic human rights," albeit "in the nicest possible way, with arts and crafts and thinking of people as spiritual beings." Camphill, moreover, was "seen as dogmatic and ... basically not as open as anthroposophy is." ${ }^{55}$

What this means in practice is that some aspects of anthroposophy live in Camphill not as expressions of ancient tradition but as new elements contributing to the renewal of community life. One powerful way in which I have seen this happen is the way some Camphillers apply Rudolf Steiner's teachings about individualization, expressed in what is sometimes called the "Sociological Law," to the changing dynamics of their movement.

Rudolf Steiner taught that humans participate in a cosmic dance of spirit and matter, a dance in which spirit descends into materiality and then ascends, lifting transfigured matter up with it. The descending step of this dance is both tragic and necessary for the sake of cosmic evolution. Matter is not evil; rather it is the separation or imbalance between spirit and matter that must be overcome. Steiner taught that humanity is currently experiencing a descending cycle of materialism, hardening, and individualization. He also taught that we are on the cusp of an ascending cycle of spiritualization, liberation of dormant powers, and renewed community. In such a time, the challenge is to welcome the coming age of ascent without rushing the current age of descent, since it too has a cosmic necessity.

In his Outline of Esoteric Science, Steiner presented the evolutionary history of humanity on a cosmic scale, suggesting that humans had evolved in spiritual spheres corresponding to Saturn, the Sun, and the Moon before coming to our present earth. He divided earth history into "ages" that were subdivided into "epochs." We live in the fifth of seven post-Atlantean epochs. This epoch, which Steiner sometimes called the epoch of the consciousness soul, began in 1413 and will continue until 3573. It is characterized by an emphasis on "knowing and controlling the sense world," and by a division between sense experience of the physical world and spiritual experiences that no longer involve "direct perception." Steiner assigned both credit and blame for modern science and technology to this "one-sided turning toward physical life." Even though Steiner said that we are closer to the beginning than the end of the fifth epoch, he also said that "the sixth post-Atlantean cultural epoch is already dawning." This will be a time in which humanity's separated capacities will be knit back together as "we recognize 
the manifestations of the spirit in our observations of and experiences in the world of the senses." ${ }^{56}$

The effect of such teaching was to instill a creative ambivalence among Steiner's students. Spiritually speaking, the fifth epoch is an impoverished time from which we might wish to escape, but only by embracing its unique tasks can we help usher in the next epoch. This double mandate, to embrace individualization while preparing to move beyond it, is the reason that some anthroposophists are wary of community building initiatives in general and of Camphill in particular. They worry that communal groups rely too much on older patterns of community-on the rhythms of the tribe, the race, or the religious order-and are thus not able to envision the truly free communities of the future. This may not be a fair assessment of Camphill, but it certainly applies to some contemporary intentional communities. Both the evangelical Twelve Tribes and the free-love-oriented Tamera Ecovillage explicitly strive to restore tribal or monastic structures as an antidote to the ills of modernity. From the anthroposophical perspective, that is precisely the wrong way to go about building community.

Steiner's teaching about the age of the consciousness soul is related to his Sociological Law, which he articulated in 1898, at a time when he had not yet publicly emerged as a spiritual teacher and when he was closely aligned with the individualist anarchism of John Henry Mackay. This law holds that "at the onset of culture, humanity strives to create social groups; that is when the interest of the individual is sacrificed to the interest of these groups. Further progress leads to freeing the individual from the interests of the group, and to a free development of individual needs and capacities." 57

Camphillers, in part because they have heard the perspectives of other anthroposophists who worry that their communal approach is too backward looking, have embraced the Sociological Law as an anthroposophical tool that allows them to make sense of the way their movement has, in fact, evolved. One person said that the trend toward individualization "is a necessary process" and that "as each community is becoming more individualized, so the sense of brotherliness is changing as well." ${ }^{58}$ Another said that changes in Camphill reflected the fact that "overall society is much more focused on the individual. . . . I don't necessarily know if that is a bad thing or a good thing, it is just a thing. . . . The best thing we can do is try to work with that in as much of a community spirited way as we can. I think trying to fight change by and large is usually not a good way to survive. You need to work with the changes that are coming and try to make it fit with your ideals." ${ }_{59}$ Tom Marx made the same general point with a surprising twist: the founders of Camphill, he claimed, were keenly aware of the importance of honoring individuality, but a subsequent "generation or two generations, maybe three generations" of coworkers lost sight of the anthroposophical emphasis on individuality, and promoted community in a one-sided manner. This in turn led 
to a backlash, as some governing boards repudiated incomesharing and lifesharing in the interest of protecting the individual rights of villagers. ${ }^{60}$

In the beginning, a long-term coworker at Newton Dee explained, "we really were all together in the same boat. And we all had to work so hard in every hour of the day. We would do the housebuilding together and the farming." This resulted in a strong "feeling of community," but a relatively weak "care and therapeutic impulse." But as things began to run more smoothly and money began to come in, there was more "space . . . to see to the needs of the individual." This meant better care for students and villagers, but also more focused concern for the unique needs of coworkers and their families. Reflecting on a recent personal challenge, she mused that "if there is a crisis, people stand around people and they get them through it, even if it is a mess. . . This community is better at that than twentyfive years ago, from what I hear." She added that Steiner had anticipated this in the Sociological Law. ${ }^{61}$

Steve Lyons, who hosted me and my family on our first visit to Camphill in Scotland, was eloquent on this point, and on the need for modern intentional communities to be radically different from the communities of the past. "The human being in its earth evolution is reaching its culmination," he explained,

and that has to do with the development of individuality. ... We are so much more individualized, and that has affected the way that we think about each other, the way we behave toward each other, and also the way we behave toward the earth. ... We feel this distance from the natural world and want to find a way back to it again, but it has to go through the individualizing of human consciousness. ... The individuation process will make it possible for each of us to freely choose to relate to each other in the forming of groups who have common tasks. Before ... we were groups of people, but we were not freely choosing those groups.... From our time on, we need to promote the freeing of each individual from these groups so that we can choose out of a new wisdom which groups we wish to belong to and which tasks we wish to accomplish with others. That's the basis of modern community.

Inspired by this understanding of the task of intentional community, Steve has focused many of his Camphill efforts on promoting person-to-person dialogue within the "rights sphere" of the threefold social order. "People today do what they want to do," Steve acknowledged. "Each of us is an I." But from that starting point, "If I can find a way to welcome you into my work and recognize that you are concerned about the same things I am, we can go a certain way together in helping each other to achieve what we see as our common task." ${ }^{62}$ Steve's words were echoed by another Camphiller who, after bemoaning the abandonment of lifesharing at one community where he once lived, mused that "things come and go. ... It really has got to do with individuals. Who is interested in doing this or not doing it." 63

One way that Camphillers have put these ideas into practice is by drawing on the wisdom of the growing community of anthroposophically inspired organizational consultants, most of whom encourage organizations to embrace structured 
disciplines of listening deeply to one another. In part because of Steve Lyons's influence, for example, several communities in Scotland have used a program called Ways to Quality in order to meet regulators' expectation that they have a formal structure of quality assurance. Compared to conventional auditing practices, Ways to Quality is complex. It identifies twelve fields of organizational life, and within each field it distinguishes a "day field" of tangible tasks from a "night field" of subconscious reflection. Participants in the organization meet together to evaluate their performance in each field, following a set schedule that ultimately produces a comprehensive audit. The aim is "not standardization but a thoroughgoing individualisation of the activity comprising the service. This activity demands continual creative encounter and engagement from the participants." ${ }_{4}$ By keeping responsibility for evaluation within the community, rather than delegating it to an outside auditor, Ways to Quality allows Camphill to measure itself against standards of its own choosing; even more importantly, it ensures that Camphillers are in ongoing conversation with one another about their diverse experiences of community life. "The beauty of it," one participant told me, is that instead of having a manager who asks you to tick some boxes, "WTQ is rooted in the whole community." ${ }^{65}$ For the same reason, some communities have found it excessively cumbersome. ${ }^{66}$

More poetically, another Camphiller used the image of St. Martin of Tours to describe Camphill's task in the face of the Sociological Law. Confronted with a beggar, Martin cut his cloak and shared part of it. "He's not sharing [with] everybody else and leaving himself nothing like a good Christian who gives everything to the poor. He actually is sharing between what he keeps for himself and what he gives to the other. In a modern sense, that's the ecology of ... balance between your own inner development, the development of your warmth, so you can actually continue having the capacity to share." ${ }^{67}$ Another, someone who has moved her own community away from rigid adherence to traditional lifesharing, observed, "What is really still the quest for the philosopher's stone is: how do you really build community? What builds community? Is it really sleeping under the same roof twenty-four seven, getting on each other's nerves and learning how to not? Or are there other ways of building community?"68

The Sociological Law also challenges Camphillers to become more conscious about money. One unintended consequence of incomesharing is that many people don't have to think about money at all. For some, that is a big part of the attraction of incomesharing. But it runs counter to Steiner's actual teaching, which is that the only way to grow spiritually is to become increasingly conscious of everything, and especially of those things, like money, that knit us together with other people. "Camphill suffers," explained one coworker, "from its separation from the economic sphere as far as people don't have to think about money. It becomes invisible, which I don't think was ever the intention of the threefold social order." 69 A strict practice of incomesharing, in which members of a community fully disclose their economic needs to one another and work together to discern how much 
money is available for each need, would of course be one way of maintaining a living consciousness about money. But in practice, as Camphills have become more prosperous and capable of meeting virtually every need, the incomesharing communities have sometimes skipped this step, offering everyone a basic stipend and bringing only unusual needs to the attention of the whole group.

Seb Monteux, who was raised in Camphill and remains engaged in its evolution, applied the logic of the Sociological Law to the cultural sphere. In its early days, he said, Camphill appropriately put its emphasis on the needs of the collective and assumed that "the happiness or the needs or the nourishment of the individuals" would follow from that. "But I think we haven't managed to ... see ... that there is a shift and then it starts from the individual." He then observed that while cultural life in Camphill schools has become attenuated, "the villages have managed on the face of it to maintain and keep a rich cultural life. But the maxim of the cultural life is freedom. [And] there isn't that feeling that it is a free cultural life. It is often quite pressured, it is put in the diary sheets that here is the cultural life. And so there is a veneer that there is something very rich and active, but it doesn't come out of a real desire to make it free so that people participate individually." This problem, he added, exposed a contradiction in anthroposophical critiques of state bureaucracies. Though Camphills and Waldorf schools say "that we don't want the state telling you what the curriculum should be," they often wind up doing "exactly what we are trying to move away from, by saying, I know what is right for you, I know what is good for you." Ultimately, he concluded, the aim might be "to collectively get somewhere, but ... we have to come to it in our individual way. We might all get to the same place, but we can't get there in the same way."’o

I have met many Camphillers, including those who are deeply committed to traditional lifesharing, who welcome the changes that individuation has brought to the movement. The founders, Marjan Sikkel told me, "were very, very, very motivated and I've often heard they were sacrificing themselves." But now "that has really changed. I do believe in working hard but I don't like this sacrificing myself. I think there is a bit of give and take. Love they neighbor, don't forget thyself." ${ }^{\prime 1}$ Still, many of these plaudits are tinged with sadness, for Camphillers cherish the heritage of the past. "Consciously," one Camphiller put it, "we all know that this is just the way it is going. ... People need their own space.... But we will say it with a bit of sadness and longing. Because for me that is what I met in Camphill and that is what was precious to me and it is changing." ${ }^{2}$

Ultimately, the most important challenge that anthroposophy can bring to Camphill today is not to rest too comfortably with inherited forms of community life, even (and especially) if these have served the movement well in the past. Seb Monteux made this point sharply when he heard me say that certain telltale practices (such as the use of napkin rings to mark each person's place at the table) can be observed at Camphills anywhere in the world. "I think that is a good example of 
holding on to the forms," he replied. "Of course they are comforting. They allow an outer identity." But "actually the wisdom of anthroposophy is telling us that wherever you are it has to be different." 73 Jens-Peter Linde, writing in 2001, urged that the much-neglected Camphill pillars might survive not as rules but as imaginative "metamorphoses of living realities," observing that "life in Camphill becomes slavery if we cannot free it from the stranglehold of outer life." Ultimately, he suggested, Camphill's anthroposophical work could be fulfilled at the most basic level of human interaction, for "whatever I do, and whatever I experience, is part of an initiation which embraces everyone around me."74

\section{OTHER COMMUNAL MOVEMENTS}

Just as Camphill life has always embraced the surrounding web of anthroposophical initiatives, so too it has evolved in complex relationship to other networks of intentional communities, both past and present. Though not every Camphiller has a personal connection to other intentional communities, the founders were keenly aware of their communal antecedents and of the other community-building experiments that were springing up around them. Such awareness came easily, for Camphill had much in common with several of the most enduring communal impulses the world has known. From the Unitas Fratrum of the fifteenth century and Hutterites of the sixteenth to the kibbutzim and Bruderhof of the twentieth, central Europe has continually produced communities. It has also repeatedly subjected those communities to persecution, prompting them to seek refuge in every corner of the globe, and to intensify their communal practices as a survival strategy in challenging times.

The Unitas Fratrum traced their origins to the proto-Protestant preaching of Jan Hus (1369-1415), a Czech reformer who advocated for the use of the vernacular in the Christian liturgy and for lay people to be given both bread and wine in the Eucharist. After Hus was burned at the stake and his most radical followers were defeated on the battlefield, a remnant organized themselves in 1457 as the Unitas Fratrum and committed themselves to the pacifism and economic simplicity of the Sermon on the Mount. When Catholics consolidated power in Bohemia and Moravia early in the seventeenth century, the Unitas Fratrum dispersed and went underground, with bishop John Amos Comenius (himself based in the Netherlands) establishing structures of communication and mutual care that would keep their fellowship intact for another century. In 1722, some of those who had remained in Catholic-controlled Moravia migrated to the southeast corner of Protestant Saxony, where they were welcomed to the Herrnhut estate of the radical Pietist Nikolas von Zinzendorf. The confluence of Hussite and Pietist spiritualities led to the formation of the Moravian Church (sometimes also called the Bohemian Brethren), a mission-minded movement that was soon planting 
semicommunal villages in India, Greenland, the Caribbean, and several locations in North America, including an area of northeast Pennsylvania that is just fifty miles from several Camphill communities today.

In seeking places of refuge from persecution, the Unitas Fratrum and Moravians occasionally crossed paths with the Hutterites. A communal Anabaptist group that today comprises nearly five hundred villages and forty-five thousand individuals, mostly scattered across the upper plains and mountains of the United States and Canada, the Hutterites are the largest nonmonastic communal movement in North America and-I believe-the most enduring nonmonastic communal movement the world has ever known. Hutterite history has been shaped by four distinct refugee experiences. In 1533, founder Jakob Hutter led his persecuted followers from the South Tyrol to Moravia, perhaps passing through Karl König's native Vienna en route. An expanding Austrian Empire followed them there, and in the early eighteenth century a surviving remnant of just one hundred relocated to Ukraine, where they benefited from the Russian policy of offering unoccupied lands to new settlers. When Russian policy tilted back to intolerance, four hundred communal Hutterites, along with others who had abandoned strict community of goods, migrated to the Dakotas in the 1870s. As pacifists, they resisted the draft during World War I and after two Hutterites died in military prison, the movement crossed the Canadian border in search of refuge. New laws honoring conscientious objection have since allowed Hutterites to plant new colonies in the Plains and Pacific Northwest, though about two-thirds still live in Canada.

Long before the Hutterites arrived in North America, communal history in the United States was dominated by German-speaking Pietists with a spirituality similar to the Moravians. Among the earliest of these were Johannes Kelpius's Society of the Woman in the Wilderness and Conrad Beissel's Ephrata Cloister. These groups blended the activist, biblical spirit characteristic of all Pietists with a strong emphasis on the esoteric or hidden dimensions of Christianity; in this respect they had much in common with anthroposophy. Both were planted in colonial Pennsylvania, each about thirty miles distant (in opposite directions) from the Camphill places. More enduring Pietist communities came later: the Harmony Society in Pennsylvania and Indiana maintained a strictly communal organization (holding all property in common) from 1805 to 1905 ; Zoar in Ohio did so from 1817 to 1898 ; and Amana in Iowa endured from 1854 to 1932. All three of these groups prospered economically and experienced the developmental trajectory I have labeled "evolving beyond community." Younger generations abandoned the practice of community of goods, but chose neither to disperse nor to abandon their religious heritage. All three movements survive today as towns, religious congregations, and historic sites that are managed in part by descendants of the original community members. (Amana also survives as a prosperous cluster of businesses.)

The founders of Camphill were not aware of all of this history, but they had a keen sense of their dependence on three interwoven communal strands: the 
mysterious tradition known as Rosicrucianism, the work of the Moravians, and the utopian socialist theories of Robert Owen. Karl König traced the origins of the community-building impulse in the West to the "Fama Fraternitatis," a mysterious document that appeared in 1610 and described a secret brotherhood, symbolized by a Rosy Cross and devoted to uncompensated acts of healing. The Rosicrucian ideal, König said, had inspired "an almost continuous and uninterrupted flow of trials in community building." (He also claimed that the Rosicrucians themselves continued the spiritual work of the medieval Templars, and was delighted when he discovered that the Templars had once been active just across the river from the original Camphill estate.) Within the Rosicrucian stream, he identified three initiatives as "stars" for Camphill: Johannes Amos Comenius's attempt to form a "universal college" in the wake of the Thirty Years' War; Count Ludwig Zinzendorf's Pietist community at Herrnhut; and Robert Owen's communities at New Lanark and New Harmony in the nineteenth century. König acknowledged that none of these initiatives had been entirely successful; Camphill's goal was thus not to repeat their efforts but simply to "walk in the trials and errors and achievements of these three great pioneers." He identified them as the inspiration for three "pillars" of Camphill practice. The college meeting, in which teachers gather for a holistic study of an individual child, derived from Comenius's educational theories, the Bible Evening from Zinzendorf's piety, and the Fundamental Social Law from Owen's ideals. ${ }^{75}$ In framing Camphill practice as a reformulation of earlier communal ideals, König exemplified what communal studies scholar Joshua Lockyer has called "transformative utopianism": the tendency of new communal movements to learn from the fading ideals of their predecessors. ${ }^{76}$

Karl König and the other founders were also aware of other communal movements that responded to the global crises that had driven them from central Europe to Scotland in 1938. The kibbutz movement began in 1909, a generation before Camphill, and experienced its most rapid growth in the 1930s and 1940s. Like König, many kibbutz founders were Jews from German-speaking territories; also like him, most were influenced by socialist youth movements. Just as the Camphill founders welcomed developmentally disabled "refugees" from an uncaring society, as well as refugees from communist East Germany, so too the kibbutzniks welcomed Jewish refugees from persecution in both Europe and the Middle East. The kibbutzniks achieved a dual success: they simultaneously established a communal culture that was robust enough to last for generations and helped lay the foundations for the new state of Israel. The kibbutzim achieved a peak population of 129,000 in 1989; today, about 270 communities are home to 100,000 residents. Camphillers experienced kibbutz life as early as 1958, when Carlo Pietzner traveled to Israel for an International Federation of Children's Communities gathering hosted by Youth Aliyah. He was impressed by the "spectacular show of willpower evident everywhere" in the young country, intrigued by the early kibbutz practice of maintaining a "children's community within the bigger 
community, with . . . a considerable extent of self-determination," and troubled by the possibility that all the idealism might serve no higher end than "the establishment and the maintenance of the state." Camphiller Marianne Sander visited Israel around the same time and reported in more detail. Like Pietzner, she was impressed by the energy of the kibbutzim but troubled by their lack of spirituality. Referring specifically to the practice of children's villages, she mused that parental devotion "has been forgotten in the life of the Kibbutz and it is being replaced by patterns and systems into which life must fit itself. Life is there to uphold the system; not the system to uphold life." 77 Perhaps because of these reservations, Camphill never forged a deep bond with the kibbutzim.

Other communal movements were founded by idealists who were troubled by the economic crisis and subsequent militarization of the 1920s and 1930s. The Bruderhof was established by Christian pacifists who modeled their communal settlement in Germany on the Sermon on the Mount and on the earlier example of the Hutterites; like the Camphillers, they migrated to the UK and then beyond after being attacked by Nazis. Taena and Iona sprouted among radical Christians in the UK, just as did Koinonia and the Catholic Worker in the United States. Also in the United States, Arthur Morgan-president of Antioch College and chairman of the Tennessee Valley Authority-promoted cooperative rural communities as alternatives to what he saw as the failures of industrial society. In 1939 he organized the Celo Community in North Carolina, in which economically autonomous households owned their own homes but leased land from a community land trust; a year later he organized the Fellowship of Intentional Communities, an umbrella organization that was revived by latter-day communitarians in 1986. It is now called the Foundation for Intentional Community.

Both Iona in Scotland and Morgan's Fellowship in the United States played significant roles in welcoming Camphill to their respective territories. Karl König developed a friendship with Iona founder George MacLeod, a minister who served a parish "in one of the worst slums of Glasgow," and simultaneously led a group of idealistic clergy and workers who had rebuilt St. Columba's ancient monastery on the island of Iona. The two charismatic community founders met on the day König signed the contract for Camphill estate. MacLeod helped König understand his new cultural context, and within a few weeks König lectured to fifty of Iona's ministers on Steiner's view of the Gospels. In 1942, MacLeod invited König to publish a series of articles in Iona's journal, The Coracle, related to Camphill's practices. König used this opportunity to criticize mainstream medicine for fostering distance between patient and doctor. ${ }^{78}$ Though each man may have hoped to incorporate the other into his community, the two groups eventually went their separate ways in a friendly spirit. ${ }^{79}$ Twenty years later, soon after the founding of Camphill Copake in North America, Arthur Morgan's son Griscom arrived to inform the Camphillers that they were part of an enduring tradition of American communities. He advised them to recruit conscientious objectors as young volunteers, and 
immediately sent his own son John as Copake's first young coworker from the United States. ${ }^{80}$

The relative endurance of communal movements founded in the 1930s, as well as of earlier Pietist and Hutterite communities, suggests that the refugee experience may be an important element in communal success. Refugees rarely have good alternatives to living in community. If they don't speak the language of the surrounding community, they need to maintain close and cooperative connections to the handful of others who do speak their language. Perhaps they are not allowed to seek employment in the larger society. Perhaps they have previously lost all of their individual or family property, and believe that they can achieve more future security by pooling resources cooperatively. Put somewhat crassly, the opportunity cost for living in community is lower for refugees than for other people.

This aspect of the refugee experience adds a nuance to the term intentional community, which was coined in 1945 and is now the most popular designation for a communal movement in the English-speaking world. This phrase implies a distinction from the "traditional community," in which accidents of birth determine who is and is not a member. The members of intentional communities, so the notion goes, are there only through active intentionality-they could be someplace else but have chosen to be here. This is only partially true for refugees and, in Camphill's case, for people with learning difficulties who may have been placed in community through the initiative of parents or social workers. The necessity of the refugee gives a needed ballast to the free-floating intentionality of the volunteer.

Another strength that refugees bring to community is the fact that they often carry a cherished vision of the society they have lost and hope to re-create. Karl König never broke faith with what he regarded as the true spirit of Central Europe, epitomized in the Vienna of his youth. He referred to Camphill as a seed of social renewal, and encouraged Camphillers to preserve aspects of Central European culture regardless of their physical location. One consequence of this is that most Camphills have a distinctive look and feel to them. Visitors have an immediate sense that they have arrived somewhere in particular, and people who spend time in one Camphill will immediately recognize the Camphill spirit when they visit another. Indeed, a common game among English-speaking Camphillers is to try to discern which aspects of Camphill are unique to Camphill, which are rooted in anthroposophy, and which are part of the general culture of the German-speaking world.

A third strength that refugees bring to community is a bit paradoxical: refugees are, almost by definition, people of privilege, and they are able to apply their considerable privileges to the task of building community. To clarify this point, it may help to note the distinction between "refugees" and "internally displaced persons," as defined by the United Nations. An internally displaced person is anyone who loses their home because of violence, war, or persecution. In order to become a refugee, it is not enough just to lose one's home, one must also cross 
an international border. Only then is one eligible for protection by international law. Only a third of displaced people today have crossed a border, and far fewer have made it to a country that does not directly border their country of origin. Those few are privileged in two senses. First, many of them started out with the economic or educational resources that enabled them to travel far distances from the homes where they started. Second, once they arrive at their destination, they have sponsors-governments, nonprofits, and private individuals that are eager to provide them with support.

The founders of Camphill became refugees about a decade before these definitions were formalized, but they enjoyed both sorts of privilege. Most were highly educated professionals, including several doctors, and they were already part of the international support network that is the anthroposophical movement. The vast majority of Central European Jews did not enjoy these advantages and were not able to escape the violence of Nazism. Once they had arrived in the UK, Camphillers quickly found wealthy sponsors who, enthralled by their vision of care for persons with disabilities and by their refugee story, offered large estates as the sites of community. As a consequence, life in Camphill can bring the opportunity to live on a stunning seaside estate, in an elegant castle, or in a rural village that regularly hosts the finest classical musicians from New York City.

To some extent, the strengths that refugees bring to intentional community last only as long as the founding generation. But there are a few ways in which the strengths can persist over multiple generations. First, the refugee generation, through a contribution of its own hard work and the financial gifts of its sponsors, often succeeds in putting a fledgling community on a solid economic footing, ensuring that future communitarians will not have to sacrifice as much to live in community as the founders did. Second, the boundary between the refugee generation and those who come after may be fuzzy, with the share of community members who have been refugees declining very gradually over time. This shelters the community from the abrupt shock that might be experienced with the sudden death of a charismatic founder. The transition can be extended even further if - as was the case for Camphill, and also for Shaker villages, kibbutzim, and many other communities-a significant number of newer members are also refugees, either literally or metaphorically.

Nevertheless, Camphill and its sister communities must also recognize that they cannot rely forever on their refugee roots. A thriving community must eventually be planted in its own soil. Karl König expressed this at the first Whitsun celebration in Kirkton House-even before the group had moved to Camphill Estate-when he told his friends that "we would not live in our new country as foreigners, but would learn to act for its good in the service of the needs of its handicapped children, even if only in a preparatory way." ${ }^{11}$ Yet he never lost his sense of the initial value of the refugee experience. As he announced sixteen years later, at the founding of Botton Village, "the outcasts of today are to be the forerunners of the future." ${ }^{2}$ 
Like Camphill, many of the communal movements founded in the first half of the twentieth century must now choose between the paths of evolving beyond community or creative symbiosis with neighbors. Iona, for example, has downplayed shared living and economic cooperation in order to prioritize its work of holding retreats and seminars about monastic spirituality. In 1992 Koinonia abandoned incomesharing and reorganized as a community development organization in order to deepen its partnership with its African-American neighbors, many of whom supported its mission but did not wish to live communally. But in 2005 it reversed course, reaffirming its original self-definition as an intentional community. ${ }^{83}$

The kibbutz movement, quite famously, has been "evolving beyond community" for at least a generation. Historically, kibbutzim have been legally required to hold all property in common and support their members based on need rather than the work they perform. After an economic crisis in 1985, many kibbutzim began breaking these rules, and in 2005 the Israeli government sanctioned an alternative. The new, "reforming kibbutzim" could pay differential salaries, often coupled with a social safety net. Typically, they also allowed nonmembers to live, work, or study within the kibbutz, and reduced democratic control of business activities. By 2011, more than three-quarters of kibbutzim identified as "reforming."

As Pitzer's theory of developmental communalism might suggest, this change enabled a new flowering of kibbutz ideals. Before the change, most kibbutzim were losing money and losing members. Now, most are stable. It turns out that many people who don't want to join a kibbutz do want to experience the cooperative culture of the kibbutz as employees, renters, or students in the popular kibbutz schools.

The evolution of kibbutzim beyond community is not the whole story, however. For much of the movement's history, it thrived because of the depth of its symbiotic relationship with Israeli society as a whole. Many kibbutzim are actually older than the State of Israel. Many of Israel's founders were kibbutz members. Several kibbutzim were established on desert lands that did not appeal to private settlers. Others chose locations where they faced the hostility of Arab neighbors. This contributed to the military goals of the new nation. By instilling cooperative values in their young people, the kibbutzim produced good soldiers. They also produced good socialists, which benefited Israel's ruling Labor Party. But the kibbutzim began to experience decline when the conservative Likud Party came to power in 1977. Likud enacted neoliberal economic policies that made it harder for the kibbutzim to manage their debts. This illustrates a danger inherent in the path of symbiosis. The more a community relies on its neighbors, the more it is vulnerable to social change.

Today, there is much evidence of new forms of symbiosis that could allow some kibbutzim to retain their distinctively communal features. Several newer kibbutzim are explicitly religious rather than socialist in their ideologies, and these have not experienced the same trend away from communalism. There are also newly founded urban kibbutzim, as well as other intentional communities, that 
seek to rekindle the spark of idealism their founders perceive to be fading at the older kibbutzim. Some of these newer communities explicitly seek to foster harmony between Jews and Arabs, or promote permaculture and other techniques of sustainable agriculture. There is also one specifically anthroposophical kibbutz: Harduf, founded in 1985 in Galilee. Harduf includes a Camphill-style curative home for children with special needs, and in 1979 Kfar Rafael was established as a village community in the desert near Beersheba ${ }^{84}$ In these places, the traditions of Camphill flow together with those of the kibbutzim.

Camphill and the other intentional communities of the 1930s interact today with the many communities formed as a part of the hippie movement of the $1960 \mathrm{~s}$ as well as a host of more recent initiatives. Notable among them is the movement that is most easily compared to Camphill: L'Arche. This international network, consisting mostly of household-scale communities for persons with and without intellectual disabilities, was founded by Jean Vanier in 1964. In 1975 Judith Jones, a Camphill visitor to the original L'Arche community at Trosly in France, "was struck not so much by differences in life-style and ideology, but by what we share in spirit"-and especially by L'Arche's "spirit of prayer and how naturally it is part of life." The same visit took her to Lanzo Del Vasto's Gandhian community in France, also known as L'Arche, and to Taize..$^{85}$ Some of the closest ties between Camphill and L'Arche have developed in Ireland. The Ballytobin community began in the same area and almost simultaneously with the first L'Arche house in Ireland, and the same Catholic curate helped both communities get off the ground. On one occasion, Therese Vanier, the sister of L'Arche's founder, intervened to defend Camphill from criticism by a Catholic bishop. And in 2003 Camphill joined with L'Arche to form a "Lifesharing Alliance" to ensure that the perspectives of lifesharing communities would be reflected in new Irish national standards for programs serving people with disabilities. After twenty years of partnership, Camphill Patrick Lydon reported that it "was a tremendous eye opener" to encounter a movement that was at once so similar and so different: "We had a wonderful experience of 'liking them as much as we liked ourselves.' In fact, we liked them better because we did not know all their dilemmas and failures as well as we knew our own!"86

Probably the two most rapidly growing models of intentional community in the world today are cohousing and ecovillages. Cohousing communities, which emerged in Denmark in 1967, are legally structured as condominium complexes, with individuals or families owning private apartments, but they also include abundant shared spaces with the expectation that residents will participate in common meals, community celebrations, and regular work shifts to maintain the common spaces. Ecovillages have a variety of ownership structures; what they all have in common is a commitment to living in harmony with natural systems and to sharing their own best practices with the larger community of environmentalists. To a degree, these two movements epitomize the contrast between the 
developmental paths of "evolving beyond community" and "creative symbiosis." Cohousing begins with a structure that is similar to that of second- or third-generation communities that have loosened their original communal commitments; it is an attempt to find a balance of individual freedom and cooperation that can be sustained long-term. Ecovillages, meanwhile, actively cultivate symbiosis with the broader environmental movement. They participate in climate change activism and host educational events (such as permaculture courses) intended for people who may not wish to live communally.

At present, the Camphill Movement does not have a deep relationship to either cohousing or ecovillages. Though many Camphillers are aware of these growing impulses, most have not directly visited an ecovillage or cohousing development. Yet several thought leaders in Camphill have suggested that these models have much to contribute to Camphill's future development. Jan Bang, a former Camphiller and kibbutznik who has written books on ecovillages and permaculture, as well as on Camphill, has pointed out that most Camphill places already meet the definition of an ecovillage, even if they do not use the term. ${ }^{87}$ What is more, environmental practices are already one of the major ways that Camphill places build symbiotic ties to their neighbors. They sell organic and biodynamic products at community groceries or through CSAs, they offer neighborhood-based composting services, they send volunteers to civic clean-up events, they host camps and courses on environmental themes, and they provide consultants to help neighbors with clean energy or water treatment projects. These are precisely the activities that ecovillages use to ensure that outsiders will be invested in their futures.

Similarly, some Camphillers see cohousing as an economic and legal paradigm that might help them avoid the pitfalls inherent in their current nonprofit status, and address the concerns of critics who portray them as segregated institutions for people with disabilities. There are two ways this might work. On the one hand, a Camphill could reorganize its residential life on the cohousing model, without changing the mix of residents. Cohousing would give Camphill residents, both those with and without disabilities, more direct democratic control over the community, since cohousing communities are directly governed by their resident owners rather than by "outside" boards of directors. As a system of ownership, cohousing would give residents more freedom to choose the type of residence that suits them best, and more protection against eviction or relocation. It would also sharpen the distinction between residential and work life at Camphill, making it easier for individuals to participate in one but not the other.

More radically, the cohousing model could be used to shift the balance among types of residents in a Camphill. Residences could be marketed to people who neither need specialized support nor wish to provide such support to others. These might be individuals who value Camphill's style of community life but have other professions they are not willing to forego; some of them might be people with disabilities who cherish the ideal of inclusive community but are not eligible for 
funded support services. If, as a result of such recruitment, the share of Camphillers with special support needs declined somewhat, this would make it easier to demonstrate that Camphill is committed to social inclusion rather than segregation, while still allowing residents with intellectual disabilities to forge strong friendship networks with one another if that is their preference. This model was proposed (without specific reference to cohousing) as early as 2007 by Eric Hoyland of Oaklands Park in England, who called it a "third way" distinct from either a stubborn refusal to change or the outright dissolution of village communities. It would create "an environment . . . which would allow an expanded freedom of movement and association for people with learning disabilities who cannot cope with the size and dangers of city life," as well as those "who can cope with life in the city but are nevertheless lonely or isolated or bored." ${ }^{88}$ A variation on this theme has been achieved by the Hertha Living Community, founded in Denmark in 1995 by people with Camphill roots. At Hertha's center are three lifesharing houses that support people with special needs, while the surrounding village consists of cohousing units that may be purchased by anyone interested in village life. ${ }^{89}$ Such synthetic experiments suggest that other intentional communities can be a vital part of the symbiotic web of neighbors who help Camphill maintain its own communal traditions-just as Camphill can make it easier for other communities to follow the path of creative symbiosis.

\section{ENVIRONMENTALISM}

Similar symbiotic possibilities can be found in the environmental movement, including but not limited to its specifically communal dimensions. From the beginning, Camphill had a connection to the environmental movement because it had a connection to anthroposophy. Rudolf Steiner's method of curative education was just one of several practical "initiatives" that he had introduced to his students, and one of the most widely embraced was biodynamic agriculture. The first internationally organized strand of the organic agriculture movement, biodynamics sees each farm as a living organism, refuses to use chemical fertilizers or pesticides, nurtures the soil through composting, companion planting, and alchemically designed "preparations," and channels cosmic influences by planting according to the cycles of the moon and planets. None of the Camphill founders were biodynamic farmers, but all were interested in farming as a healing practice and a source of symbolic correspondences that might illumine their own therapeutic work. It is no accident that the collected writings of Karl König include an entire volume devoted to "social farming" and another to animals.

Much of Camphill's environmental vision crystallized with the founding of Botton Village in 1955. As an adult village, Botton could not appropriately claim that its "work" was care for people with special needs: that would undermine their human dignity as adults with their own vocations of work and service. But 
the Camphillers had long yearned to connect more deeply with Rudolf Steiner's teaching on agriculture, and the sheer extent of the Macmillan estate-which encompassed four distinct farms and 280 acres of farmland-gave everyone an opportunity to develop their capacities for hard work on the land. "Those who are handicapped," explained one founder, "can take their place in the community and can participate in mankind's responsibility towards the earth."90 And the editorial celebrating Botton's founding in Camphill's journal dwelled at length on the ecological crises that the village might help heal: "Earth—how many hundreds of acres slip away yearly, hopelessly eroded by chemical overtreatment! Water-read the daily papers, read of empty reservoirs, receding ground water, polluted rivers and lakes, oil-encrusted oceans!"91

For Karl König, agriculture was an essential practice for Camphill because a living connection to the earth had the potential to draw the community out of the isolation of the refugee experience. "Wherever maltreated, outcast and stunted human existence is to be restored to the holiness of true humanity," he mused, "'villages' arise. ... [But] these are very seldom real villages. They become settlements and are thereby without the curative element and the healing stream of Mother Earth." He envisioned that the practice of farming and gardening would gradually extend Camphill's reach to include "tradesmen, artists and craftsmen" and also to "guide parents in such a way that their children may become people who, out of a civilization in decline, are able to be the seed-bearers of a new culture."92

These ideals were still alive in 1975, when one Camphiller referred to "curative education and agriculture" as the "two pillars" of the village impulse, "stand[ing] in our Villages like the pillars Boas and Jachin in the Temple of Solomon." ${ }^{93}$ Another, reflecting on Botton Village's coming of age at its twenty-first anniversary, stressed that "care for the handicapped" cannot be the primary work of a Camphill village because "the handicapped are workers with us." The villages' mission, therefore, was "to heal the earth," primarily through biodynamics. ${ }^{94}$

The Camphill approach to agriculture also has the potential to challenge widespread assumptions in the broader environmental movement. In a 1975 article, Hartmut von Jeetze, then a farmer at Camphill Copake, challenged the belief that "the cultivation and care of the land" is part of the economic sphere. Highlighting the etymological connection between "culture" and "cultivation," von Jeetze stressed that "the nature of decisions underlying all acts of cultivation is one of individual spiritual activity on the part of those cultivating the land." The misunderstanding of cultivation as economic, von Jeetze went on, was linked to "cheap labour, artificial fertilizers, forced breeding of plants and animals, mechanization" and "the flight of people from the land"-all tragic "compromises" that have been widely adopted because of their "seeming success." The correct path is for communities to recognize their "indebtedness to the land" and allow their farmers "full freedom to administer the land according to methods and principles which are in harmony with the living organism of the farm," without compromises. ${ }^{95}$ In 
part, von Jeetze's claim simply echoed Steiner's threefolding theory, according to which the economic sphere is restricted to the production and trading of physical goods. For Steiner, labor actually belongs to the "rights" sphere, insofar as all workers have a right to basic sustenance, while both land and capital, as sources of new creativity, belong to the cultural sphere. But in the Camphill context, this rather abstract assignment of activities to different spheres becomes concrete, for von Jeetze's argument contains an implicit analogy between agricultural land and persons with disabilities. They too, have suffered in a society that seeks to reduce them to their economic value. Rather than insisting that they perform economically productive work, Camphill claims the freedom to help them express their human potential fully and without compromise.

A significant share of the baby boomers who came to Camphill in the $1960 \mathrm{~s}$ and 1970 os were inspired by the then-blooming environmental movement, or at least affiliated with volunteer organizations with environmental missions. Jonathan Reid, a long-time coworker at Botton Village, for example, first visited the community as part of a two-week work camp sponsored by the British Trust for Conservation Volunteers. "I was with a bunch of other young people and we were digging ditches, planting young trees.... We all camped on the floor of one of the public buildings." His own interest was more in intentional community than in conservation per se, but conservation gave him the entrée into Botton's holistic vision of community. ${ }^{96}$ Another coworker told me how her interest in herbs had steadily developed as she moved from one Camphill to another. In Ireland, she started a herb garden but did not dare trying to dry the herbs in Ireland's moist climate. When she moved to a new Camphill, she was able to take over a herb workshop from a woman who had run it for many years and could mentor her in the art of herb drying. She then moved to a third community, which enthusiastically embraced her proposal to start a herb workshop from scratch. ${ }^{97}$

Coworker Will Browne told me that Camphill had enabled him to pursue a minicareer in wastewater treatment. He first learned of Camphill when he was an architectural student and heard of Camphill's distinctive architectural style. When he visited, he was impressed by everything except the architecture, and soon found a chance to join a community. Almost immediately he was invited to work with a group of Camphillers who were using flowforms-an anthroposophically inspired device that produces a vortex within a stream or fountain - as part of wastewater treatment. "I could combine my architectural interests and training with a whole way of thinking and working which seemed to me to be very exciting. Working with nature." After exploring both reedbed and pond-based systems, the team "found that the ponds were particularly appropriate in the Camphill setting where there is an interest in wanting to integrate more with what is going on, and the educational value of having open water and ponds where you can see the different life forms. And also the aesthetic value is increased with ponds." At Camphill Devon, they even built a water treatment pond right in the middle of the village 
green. "It was very exciting how one uses something like wastewater, that is often viewed as a problem, and uses it as a resource to create something that is aesthetically and educationally valuable."

Will's wastewater work took on a new dimension when he began working in Norway, where "the nature forces ... are much less tamed. . . . You just got a feeling that humans were somehow rather insignificant compared with the power of nature.... The first ponds that we made got washed out by a flood that came the first autumn." He also came to see his effort to "redeem" the pollution caused by humanity as "a kind of Christian act. ... It was during that period that I experienced myself as a Christian. ... That also drew me towards the Camphill setting because there the religious aspect of life was not just something that happened on Sunday in a church. It was something that permeated much more of the life from the morning verses to the celebrating of the Bible Evening." Eventually, Will moved permanently to Vidaråsen, where he teamed up with the local agricultural university to demonstrate that a pond-based system could manage the water of two hundred people even through the Norwegian winter. When I met him, his responsibilities had shifted to the overall management of Vidaråsen, but he maintained a deep personal connection to the ponds he had built. "When it gets too much, I seek refuge down there with the frogs and newts and other animals." ${ }^{98}$

Will's emphasis on the spiritual dimension of Camphill environmentalism was echoed by Ruth Tschannen, who runs the garden at Cascadia in Vancouver. Cascadia is an urban community that does not rely on its garden for a significant share of its food, and she stressed that even the garden crew spends only an hour or two gardening each day. Nevertheless, she said, "I look at the garden as the vessel for everything else. If we believe in the power of the biodynamic preparations, a little garden like this can radiate into the whole city." She then told a story of a Mexican woman who visited Cascadia when they were having an art event in their garden. Since the woman didn't speak English, she asked her daughter to convey a message to the gardener. "I hope you're not offended or think we are strange," the daughter began, but "my mother wants to tell you that she has not seen so many elemental beings in a long time and she wants to say thank you." "Then she looked at me," Ruth continued, "and she could see that this is nothing unusual for me to talk about. And she just started to weep, and she came and she gave me a big hug. ... That's what I'm interested in for the city too."99

Currently, Botton Village is exploring the possibility of creating a "green prescription" initiative, in which people suffering from anxiety, depression, or other mental illnesses would join the community for a brief period in order to find healing in its gardens, workshops, and festivals. "Nature is the perfect doctor for the human being because the human being reacts to nature," explained the employee leading this initiative. "It is like a microcosm. . . . You can say, this is where you put the seed, this is how it grows. If it can flower, it has to die in order to become the seed again. And this is what we are as a human being.... The green 
prescription treats the human being and tries help by engaging his will ... into the activities, with something solid, with matter, where you put your effort into something where you see progression and it doesn't matter if you make a mistake."100

Similarly, Vidaråsen has built a "sensory garden" in addition to its many food-producing gardens and farms. This garden includes a large field of wildflowers, along with a collection of raised beds set at various heights in order to be wheelchair-accessible. As Runa Sophia Evensen Gafni explained, "One main idea was to create a space where people can come from outside and enjoy what is special here. . . . To discover for example what is a flower like in different stages. Or how amazing it is that a butterfly becomes a butterfly out of being a little worm." Some parts of the garden grow herbs that can be made into teas and medicines, while "other areas will be only for your smell or eyes. We will also play with what kind of colors we will plant together. . . . From spring to late autumn, there will always be one area that is in bloom or has a special quality." She also described the garden as a "cathedral in nature ... not restricted to one religion or one belief or one group of people or ethnicity. We are all people and nature is with us and we can meet here."

As I have argued elsewhere, one of Camphill's greatest contributions to the environmental movement is the fact that environmentalism is not its primary focus. For this reason, it excels in bridging environmentalism not only to disability and community, but also to such fields as education and aesthetics. An article in the Camphill Correspondence on beekeeping at Beitenwil in Switzerland aptly illustrates the dynamic. The Camphillers there discovered that their orchard had once had a "bee-house" (a structure accommodating as many as twenty beehives), but that it had burned down. They reached out to their neighbors, who responded with generous donations at the community's first Open Days. This allowed them to purchase an empty bee house and move it onto the site. The local "bee inspector" then alerted them to "an old bee-father who had died and whose bees were in need of a new home." Yet another neighboring beekeeper helped them transport the bees, and by the next Christmas they had one hundred kilograms of honey, and great hopes for a better fruit harvest in the coming season. This touching story of a new Camphill building up its neighborly connections inspired the newsletter editor to add a traditional Sussex round that was popular at Botton: "Bees, bees of Paradise, do the work of Jesus Christ, do the work that no man can."

Given the environmental ideals of many of the young people drawn to Camphill today, it seems likely that symbioses with environmentalism will remain a vital part of Camphill's future, and perhaps with some communities publicly identifying themselves as ecovillages. Though no Camphill has yet taken that step, I got a vivid sense of what such rebranding might mean when I visited Sólheimar Ecovillage in Iceland. Sólheimar is a sister community to Camphill whose founder, Sesselja Sigmundsdottir, was mentored by Ita Wegman around the same time as Karl König. Like many Camphill places, it evolved from a school for children into a 
village for adults, and eventually it renamed itself Sólheimar Ecovillage. Sólheimar is home to many environmental projects. Its geothermally powered greenhouses produce half of the organic tomatoes grown in Iceland, along with a host of other crops. Sólheimar has an energetic tree-planting program, including a self-guided walking trail full of information about the challenge of maintaining biodiversity in Iceland's volcanic environment. It currently does not have livestock, apart from chickens, but its director is trained in biodynamic agriculture and eager to expand the community's farming activity. Much of the community's life centers on Sesselja Hus, which is set up as a center for environmental education featuring interactive exhibits on sustainable power and Icelandic ecosystems.

Most of these activities have parallels within Camphill, such as Botton Village's tree planting program and Clanabogan's promotion of biomass heating. The big difference, though, is that Sólheimar's self-identification has put it on the map for national and international environmental tourism. Several community buildings are set up to host visitors, retreat-center style, and these are regularly rented to yoga groups, art therapy organizations, and the like. "Groups like to come here," one leader explained, "because it is quiet, you live in a nice environment, you can have healthy food, you can breathe healthy air." ${ }^{103}$ While most Camphills are reluctant to welcome young coworkers for periods of less than a year, Sólheimar regularly plays host to groups of students who come for a semester, a summer, or a visit of just a few weeks, and most of these groups come under the auspices of environmental studies. As an ecovillage, in short, Sólheimar has greatly expanded the range of neighbors who are invested in its future as a community.

\section{SOCIAL CARE IN AN AGE OF AUSTERITY}

When Camphill began in 1939, the founders spent little time interacting with the social care authorities. In Britain, as throughout the West, many people with intellectual disabilities were housed in government-funded institutions, but the de facto mission of those institutions was to keep such persons out of the consciousness of policymakers. Even before arriving in Scotland, Karl König was committed to finding an alternative. In his proposal for a curative institute-first submitted to the government of Ireland-he faulted the existing institutions for expecting persons with disabilities "to wait tardily for a miserable death." A better approach, he wrote, was to recognize that "abnormal people . . . have come into the world in order that the works of God may become manifest in them.... They all deserve that they would find a community in which they would be able to live and to take up the tasks and the work which is within their abilities." König assumed that persons with intellectual disabilities would not be able to compete within the mainstream job market, and he was wary of supported employment schemes that might harm nondisabled workers by making the products of the disabled more competitive. But he believed that special communities for persons with disabilities could be 
self-sustaining, because they would "complement one another like the blind and lame and ... form in their togetherness a whole and fully adequate community," in which "the mark of inferiority" would be removed from their foreheads. ${ }^{104}$

Camphill maintained its critical attitude toward the large society's approach to disability, even as it attracted the support of parents and social workers. At the founding of Botton Village, König incorporated his critique of intelligence testing into a dystopian vision of a coming "managerial society" in which "the manager with his special 'I.Q.' will lead the less intelligent roboters." time, Thomas Weihs commented ironically on the incoherence and contradiction of Britain's Mental Deficiency Act of 1913, which identified the categories of people who could be forcibly institutionalized. But he also noted that one of its "positive openings" was the implication that "mental deficiency is not a diagnosis of an individual condition, but that it is a term describing a social phenomenon, that is-a phenomenon of relationship between the community and the individual." Drawing on this insight into what we would now call the "social model of disability," Weihs concluded that that the proper response to mental deficiency should be "to find new social forms, new forms of community living that will accept the individual, integral personality in such a way that the developmental 'otherness' becomes variety instead of abnormality, and that diversity instead of uniformity is the foundation of social life." ${ }^{106}$

By that time, new ideas were beginning to percolate among the psychologists, and the pace of change in disability policy has not abated since. ${ }^{107}$ In 1956 Karl König reported to the other Camphillers about a series of experiments conducted by "progressive" mental hospitals, in which patients were given more attractive accommodations and more opportunities to read, do handicrafts, and perform household tasks, and proved to be far more capable than their caregivers imagined. In 1958, Britain's National Society for Mentally Handicapped Children (later known as Mencap) conducted an experiment that compared the experiences of institutionalized children with those placed in familylike settings and offered ordinary schooling. The latter group did better, giving rise to campaigns for deinstitutionalization. König observed that such successes depended partly on the enthusiasm of the participants, and warned that Camphill was also vulnerable to deterioration as "the original impulse dies down and ... human relationships go to sleep." 108

Additional research on the human costs of institutionalization justified significant changes in both the policy and philosophy of social care. In 1959 Britain's new Mental Health Act replaced the Mental Deficiency Act, bringing a new emphasis on the value of providing care "in the community" rather than in specialized institutions. In 1968, the Seebohm Report, commissioned three years earlier to review British social services, recommended policies that would shift most care for persons with disabilities into homes and small scale facilities immersed in residential neighborhoods. It also urged the reduction of "the rigid distinction between the 
givers and the takers of social services and the stigma which being a client has often involved." $1{ }^{\circ}$ This vision was echoed in a British white paper entitled "Better Services for the Mentally Handicapped" and in the proceedings of the 1973 convention of the American Association on Mental Deficiency. By the 1980s, Mencap was offering community-based housing for persons with disabilities, and in 1995 Britain's Disability Discrimination Act was passed. ${ }^{10}$

In 1969 the Swedish psychologist Bengt Nirje encapsulated the theory underlying these policy changes with his notion of "normalization." This is the idea that people are devalued when they are placed in roles or situations that differ from the cultural norm, as is the case in institutions that segregate persons with disabilities and treat them exclusively as recipients of care. The antidote, logically, is to ensure that persons with disabilities (and, indeed, members of all stigmatized groups) have access to all of the resources, life circumstances, and social roles available in the larger society. This theory underlay the rapid embrace of deinstitutionalization in Scandinavia in the 1970s. In the United States it was adopted by Wolf Wolfensberger, who guided many deinstitutionalization programs from his research center at Syracuse University. Wolfensberger eventually preferred the term social role valorization, which avoided the misleading assumption that there is universal definition of "normality." His point was that the best way to protect people from dehumanization is to place them in roles that are valued in their specific cultural context. Wolfensberger also believed that government funding exacerbated institutional dynamics, and perhaps for this reason he maintained warm ties to both L'Arche and Camphill. He got to know Helen Zipperlen and other residents of Camphill Village Kimberton Hills during the campaign to shut down the massive Pennhurst hospital, located not far from Camphill. His ideas shaped Kimberton Hills's decision (somewhat rare in the larger Camphill context) to refuse licensure and government funding; his colleague John O'Brien also supported Zipperlen's "Safeguards" project, which identified strategies for ensuring safety in unlicensed communities. ${ }^{.11}$

Other Camphillers responded to normalization theory with more caution. In a newsletter editorial that mostly praised the new emphasis on the integration of persons with disabilities into the larger society, Richard Poole warned that "like all good things, integration carries its shadow with it." He reminded Camphillers that "the all-powerful state is in the saddle behind many campaigns for "normalisation."112 Jeff Balls sounded a similar warning in a reflection on the multiple meanings of "integration." Drawing on Charles Reich's New Left critique of the "American corporate state," Balls suggested that mainstream society caused disintegration by forcing people to act as both disciplined producers and hedonistic consumers. Balls concluded that "if, on the one hand, we can help people, handicapped or otherwise, to become integrated, to gain integrity, and on the other hand work towards an integrated society, a society with integrity, then the problems associated with integrating people into society will be very much less 
formidable." ${ }^{113}$ Similarly, Botton Village founder Peter Roth acknowledged that the call for integration was an attempt to honor "the dignity of the human being," but warned against simply integrating into a "normality" that "is inextricably permeated by inhumanity." True integration required an active commitment on the part of persons without disabilities to join their handicapped neighbors in the work of "running coffee houses, restaurants, shops in town, farms, gardens, forests in the country."114 These arguments ran parallel to the criticisms of normalization voiced by disability studies pioneer Michael Oliver around the same time, yet as far as I can determine Oliver and the Camphillers were unaware of one another. ${ }^{15}$

By the middle of the 1970s, it was clear that the Seebohm Report's vision of care in the community would not be fully realized (in Britain or in other societies with similar policy aspirations), simply because appropriate day programs were not being created rapidly enough to accommodate the thousands of people being discharged from residential facilities. Instead of becoming part of the larger society, many people with disabilities were "now totally isolated, lonely and almost forgotten." The Camphill town community at Stourbridge responded by creating a "Community Care Club" where people gathered to do crafts together, as well as playing games, singing, watching films, and holding conversations. ${ }^{116}$

In 1975, a government commission in Norway called for persons with disabilities to be moved from residential to day programs. Camphill, as well as other residential programs, was "caught between the pressure to bring the handicapped out into the 'normalcy' of society, and the grim reality of a 'care' programme that has laid little foundation for integration." But the Norwegian Camphills were well placed to meet this challenge, for they had already begun promoting "a conscious 'flow' between village and surrounding neighbourhood." They also had many allies, for thousands of Norwegian school children had raised money for Camphill by selling candles. In this context, government officials saw Camphill as "one guide-post in an otherwise uncharted landscape." ${ }^{117}$ Ultimately, Camphill received its own special line item in the national budget even as older institutions were shut down. Camphill in Norway still benefits from this arrangement, operating with greater freedom than is possible in virtually any other country. But in a sense the Norwegian story reveals the seed of Camphill's later struggle in the UK and elsewhere. Precisely because Camphill offered such a high standard of care in the 1970s, Camphillers did not participate fully in the new conversation about normalization. They engaged it intellectually, but then fell back on the superiority of their own practices, rather than struggling deeply to connect the best insights of their traditions with the best insights of the new approach.

The 1970 conversation about normalization also provoked Camphillers to engage fundamental questions about the nature of intentional community: Was Camphill a utopian alternative to the rest of society or a renewing impulse within that society? When Camphillers at Hogganvik in Norway asked, "Do we really want to encourage villagers to go back into society, if what we want to create in 
the village is an alternative to this society?" they realized they had to ask, "Is the Village an aim in itself or is it a station on the way back to society? If the Village is a lasting alternative system, how should we then build a bridge into society at large?" Such questions were given extra poignancy by the fact that Camphill had not been consistently welcomed by their local community; only after two and a half years of deliberate outreach did they persuade a villager from the local area to join Hogganvik. But once that happened, they were in a position to discuss "another type of integration": taking action to preserve a declining rural community by taking on local enterprises, such as a bakery and a laundry, that were closing down. ${ }^{118}$

Social care policy took a new turn in Great Britain with the election of Margaret Thatcher as prime minister in 1979. Thatcher turned back four decades of expanding governmental services, promoting private enterprise and free trade as panaceas for all that ailed humanity. Her politics of austerity spread to the United States during the Reagan years, and to a lesser degree infected most of the other nations where Camphill operates. Ever since, social care policy in the West has had two faces. On the one hand, policymakers seek to promote the human dignity and social inclusion of persons with disabilities, and they have relied heavily on inspections and regulations to achieve this goal. On the other hand, they have been asked to spend ever less money on the task.

Camphillers, for the most part, oppose Thatcherite politics of austerity but are ambivalent about the trend toward greater regulation of social care services. They wish to honor human dignity and to promote full inclusion within their communities and in the larger society, but are not convinced that inspections and regulations are paths to this goal. "People say yes we want it person-centered and the person is important," explained one coworker in Ireland, after questioning the need for "a very detailed and intellectualized style of record keeping." They also struggle to discern which policies are genuinely motivated by a commitment to human dignity and which are the fruits of austerity. Two buzzwords in twentieth-first-century social care are personalization (also known as self-directed support or individualization) and care in the community. Personalization refers to the goal of allowing each person with special needs to choose a unique package of care from a wide variety of choices, with residential and workplace services ideally being offered by different providers. "Care in the community" assumes that, since all people have a right to be fully included in mainstream society, all forms of care should be provided in settings that are as little removed from the rest of society as possible. The idealism underlying both approaches is self-evident, yet both hold out an illusory promise of reducing the overall cost of social care. Self-directed support encourages price competition among care providers, while care in the community hopes to replace residential care facilities and sheltered workshops with private homes and paid employment. In such a compartmentalized system, it is not clear that anyone is responsible for ensuring the holistic wellbeing of persons with disabilities. 
By undermining the idealism inherent in aspirations toward personalization and care in the community, austerity sometimes made it easier for Camphillers to avoid the critical self-examination that those ideals might have provoked. If Camphill life in practice was superior to "care in community" as practiced under conditions of austerity, why should Camphillers rethink their own approach? It soon became common for Camphillers to draw ironic contrasts between "care in community" and their own more authentic vision of community life. At the opening of a new Camphill farm in 1993, Peter Bateson promised that it would provide "not 'care in the community' but life in community, an active working, social and cultural life, in a setting and in circumstances which make possible real mutual understanding and mutual support." ${ }^{120}$ Two years later, the founders of Camphill Cherry Orchards promised to provide "caring communities" as an antidote to "the failure of the 'care in the community' policy." ${ }^{121}$ Such rhetoric made sense to Camphill insiders who understood that the criticism was directed at austerity rather than inclusion, but it did little to invite dialogue with sincere advocates for "care in the community."

One positive side effect of the politics of austerity is that many Camphill communities have forged new partnerships in the hopes of preserving the integrity of their work. In about the year 2000, the Irish Camphills negotiated a new agreement, called "Enhancing the Partnership," with the government bodies that funded their work. This involved a good bit of anxiety, as Camphillers worried "that the State, so tied to financial considerations, so transparently materialist, is incapable of more than a short-term commitment because its primary allegiance is to public opinion." So they convened a series of conversations with friends involved in other charities, in government, and in education, to articulate the components of authentic partnership: equality, trust, "creative tension between diversity and unity," and a "will to enhance and empower the Other." Reflecting on these conversations, participant Patrick Lydon articulated a core dilemma. On the one hand, "we know that to move on we must find our place in the mainstream, in the market place of society." On the other, "there is a genuine and justified fear of being overwhelmed by the pervasive force of the market place." This dilemma is not unique to Camphill: it is the challenge of every organization that seeks to preserve non-market-based ideals within a neoliberal society. ${ }^{122}$

The politics of austerity has also challenged the Camphill practices of incomesharing and lifesharing. When unpaid volunteers maintain comfortable middleclass lifestyles, it is easy to ask questions about whether incomesharing is simply an elaborate tax dodge. As Thatcherite policies of austerity reduced funding for social care in the UK, social care authorities often demanded that Camphills link each line item in their budgets to care for persons with special needs. It might be acceptable to pay a high salary to a highly credentialed specialist like a doctor, but unacceptable to pay the school fees of the children of farmer with minimal care 
responsibilities. From the perspective of these authorities, lifesharing is suspect because it is difficult to disentangle money spent for the household needs of people receiving care from money spent for the needs of those providing care. Lifesharing can also make it difficult to respond to accusations of sexual or physical abuse. Ordinarily, the person accused of abuse would be removed during the investigation of the accusations, but when this person and their family are part of a common household, this disrupts the lives of everyone living there.

Especially in Great Britain, questions about incomesharing and lifesharing have accompanied an overall increase in regulative oversight. Intensive inspection of schools serving children with learning difficulties began in the 1980s, and similar inspections came to the adult communities in the 1990s. The governmental bodies charged with overseeing care services for persons with intellectual disabilities have changed multiple times since the beginning of the century. In England, the Commission for Social Care Inspection was created in April 2004 to consolidate the work of several distinct regulatory bodies, but just three years later the regulation of services for children was moved to a different body, and in 2009 the Commission for Social Care was replaced with a new Care Quality Commission. The Scottish Care Commission began in 2002 and was consolidated with other organizations to form the Care Inspectorate in 2011. In the Republic of Ireland, the Health Information and Quality Authority was established in 2007, with a mandate to greatly expand oversight of social care facilities in the wake of several well-publicized scandals at a variety of care institutions. ${ }^{123}$

By the time I began visiting Camphill places, the pace of change had accelerated to the point that many Camphillers viewed changes in the social care establishment as the most significant challenge for Camphill's future. "It is changing dramatically," said one person who, as a state employee charged with overseeing Camphill's regulatory compliance, was partly responsible for the changes. Because the authorities were no longer willing to send children who could be educated in the mainstream schools, the only children coming to Camphill were the ones "who can't be educated in school and the situation at home has broken down and they have extremely challenging behaviors." Young coworkers were not always able to manage those behaviors, and so they had to hire "very specifically trained staff ... which changes the whole ethos of the community." What's more, regulations both small and large were undermining lifesharing: "The children can't all sleep in one room. You have to take the temperatures of the fridges. You have to make sure that there are menus on the wall. You have to make sure that your doors are locked. You have to make sure that these children are kept safe. You have to let us know if anything happens to these children." The stress of following so many rules, she concludes, was causing "a lot of disillusionment in the community".124 A coworker who had come to that community from a Camphill in England described similar changes with a sharper edge. 
Everything had to start being documented. Some of it definitely very important, like medication. ... But towards the end of the thirty years in Devon, it became so that you couldn't ask the adults to do anything. You could encourage them. But you couldn't demand of them to do anything. And that was a great shame because a lot of people have their weaknesses in the realm of the will forces. And yet if you can encourage them and support them, they are so happy when they have achieved. They have baked a batch of bread or they have made yogurt or they have done their work in the garden like everyone else. We were a real working community. But towards the end it was becoming more a babysitting service. ${ }^{125}$

Angelika Monteux told me that the pace of change in Scotland had been greatest at the turn of the century, when adjusting to the new regulations meant learning "to use a different language." This wasn't wholly bad though, she said: "I realized that . . Camphill isn't the only place for children with special needs. There are other people that have good ideas as well and one can work together. That was a big eye-opener." ${ }^{126}$ Her experience was typical of many Camphillers in Scotland. "Some of the early inspections went quite well," explained a Camphill Scotland staffperson, "and some of them didn't go so well. What was targeted was things like health and safety. A kind of lax approach to electricity and water and things being left lying around and so on." Many of the inspectors were brand new to the work and focused on trivial things, and some Camphillers reacted by refusing to cooperate with them. But a larger number of Camphill's leaders, said Neil Henery, "really took on the challenge of working with the Care Commission" by implementing recommendations in ways that would improve Camphill. ${ }^{127}$ One of those young leaders, Tom Marx, reported that he "had heard it reported from all quarters that the Care Inspectorate are terrible," so much so that he had to ask an older coworker to step out during an inspection. Once he could engage the inspector directly, "I realized that the bloke actually wanted to help us. But he didn't have the language that we were using and we didn't have the language that he was using. . . . These guys who were inspecting us actually liked what we were doing and they were keen to point us in the right direction." "128 By 2013, leaders in Camphill Scotland were cautiously optimistic that they had "cracked the Care Inspectorate issues." This was possible both because of the creativity of the Camphillers and because Scotland is a small polity with a deep and well-known Camphill history.

Some small Camphill places have been able to create similar niches for themselves. When Camphill Cherry Orchards became a registered care home for persons with mental illness, explained Stephen Sands, they "were immediately under a very stringent series of regulations, some of which were annoying and practical like size of rooms and sinks, placement of fire extinguishers, and that kind of thing. Others were, we felt, very sensible . . not something to be pushed against, but rather to be developed out of our own ethos and lifestyle." Because Cherry Orchards was moving into the (for Camphill) new field of mental 
health, they were committed to cultivating good relationships with the psychiatric establishment, recognizing that "there were psychiatrists out there who were [also] frustrated and being disempowered by the system as it was." They "wanted to have a cooperative gesture whenever possible. And be very clear about where we stood, but be willing to actually listen to what others wanted to say to us."129

At Camphill Glencraig in Northern Ireland, I heard a paradoxical story about government inspections. Because Glencraig includes both a school for children and a village for adults, it fits awkwardly into government categories and has experienced a confusing mix of intensive inspection at some times and benign neglect at others. Overall, Vincent Reynolds reported, "the weaker we've become, I've experienced more support coming from the authorities." When inspections began, they were a strong and cohesive community, and "maybe there was a certain arrogance that we were going to do it ourselves." By the time of their 2007 inspection, on the other hand, school enrollment was declining and there was a real question of whether it would survive. The inspectors responded with a strong affirmation "that there is a need for Glencraig. ... For the children who were here, there wouldn't be another place for them." A survey of other special schools identified sixty children whose schools were "struggling to meet their needs," and who might be well served by Glencraig. ${ }^{130}$

Changes in social care regulation have been much more devastating for many Camphills in England. Some of these communities received such negative inspection reports that local authorities refused to place any new persons in their care. These inspections came at a time when many communities were already struggling to recruit lifesharing coworkers. The board of the Camphill Village Trust responded by curtailing its practice of both incomesharing and lifesharing. It first transitioned most of its smaller places to an employee-only model, then in 2015 implemented this policy across all its constituent communities, including those that still had vigorous groups of long-time coworkers. I shall discuss the consequences of this conflict later.

In several cases, Camphill places have been forced to abandon lifesharing in the wake of allegations of physical or sexual abuse, or after failing to develop a consistent plan for preventing abuse. This is a source of much soul searching for Camphillers. On the one hand, they are keenly aware that abuse has taken place in Camphill, and that Camphill as a whole could do a better job of safeguarding against it. On the other hand, many Camphillers worry that bureaucratic responses are not guaranteed to succeed, and that they can also cause much human damage. Many tell anecdotes of coworkers who were removed from communities because of allegations that were never substantiated. Diedra Heitzman noted that the state of New Jersey, as one example, requires coworkers to sign a statement agreeing to report any incidents of abuse. It also defines "willfully ignoring" someone as a form of abuse. But what, she asked, if someone has a habit of asking the same question dozens of times? Is refusing to answer for the forty-fifth time willful ignoring? 
"What if a young person comes in and sees something they don't understand and chooses to call the state of New Jersey?" "131

The changes in social care regulation have contributed greatly to the workload of Camphill coworkers, who spend more time filling out paperwork and less time interacting directly with the people with whom they live. "Evidence, that is what they are looking for," explained one coworker in Scotland. "Each year we write an eighty-page document and provide another full folder with evidence of how we do things. . . . It is a lot of work, to be honest." ${ }_{132}$ Another cost of the increased workload is a loss of time available for other activities. One long-time Camphiller suggested that people simply have less time for anthroposophical spiritual practices, seasonal festivals, and performing arts. "Twenty or even fifteen years ago it was something which was almost taken for granted. Now it requires an ever greater effort to find a time for say putting on rehearsals and freeing people from other activities." 133

The notion of "personalization" brings other challenges to Camphill. Increasingly, policymakers see persons with learning difficulties as citizens with specific rights, among them the right to purchase their services from a menu of choices, even if that means splitting up the services that Camphill once provided in a comprehensive way. The logic of citizenship-which many Camphillers would endorse-is thus tangled up with a logic of consumerism that they are inclined to resist. "Personalization is a way of trying to help services attend much more closely to the needs, wishes, wants, preferences of individuals," explained Camphill Scotland's director, Neil Henery. "Camphill because of its traditions has lots of strengths in that way already," but they are not always visible to people who have "preconceptions" about Camphill and its worldview. Moreover, under personalization "service users are almost treated as if they were customers, so that the customer with the widest proactive choice is the happiest customer." 134 Another person said that "with the Care Inspectorate, the rights of the individual are all important. ... If the person wants it, the Care Inspectorate will come in and [insist that] they've got a right to it. I remember, we had what we viewed as a wonderful menu with biodynamic food, everything was fresh ... grown ourselves in our own fields, our own potatoes, our own carrots. .. . The Care Inspectorate came in and said, where's the choice of food on the menu. . . . I said, we are trying to emulate family life. How many families have a menu?" 135

Some Camphillers view these trends through the lens of Rudolf Steiner's account of the two demonic figures, Lucifer and Ahriman, who vie for power over humanity. Lucifer is the demon of excessive spirituality who tempts us to ungrounded idealism; Ahriman is his materialistic rival who would bind us to the physical world; and Christ's role is to chart a balanced path in between. In the context of this paradigm, bureaucracy is "Ahrimanic" - and, in my experience, Camphillers spend more time worrying about Ahriman than about Lucifer. According to the regulators, groused one Camphiller, "a room has to be so many square meters and 
you have to have a sign on the door to the bathroom, even though Johnny and George know where the bathroom is. .. But then you take away agency from them, because they know where the bathroom is." ${ }^{136}$ In Ireland, Tobias Pedersen observed that increasing regulation "is good because it makes us look at our own practices, and we can improve." But "we can also go over the top with so many policies and procedures that the actual living together and working together is not there anymore." When "the Ahriman factor comes in," he went on, "everything has to fit into a neat box where you can either put a tick or cross on it." Things may be neat and hygienic, with "incredible policies ... but is the community any happier? ... I wouldn't say [it is] unhappy, but the quality is gone. The spontaneity. Because you can't have a policy for spontaneity. And I suppose the friendship, love, spiritualism, doesn't have a box. You can't box spiritualism." ${ }^{137}$

When Camphillers describe regulations as "Ahrimanic," they are not necessarily rejecting them. The cardinal anthroposophical value is balance, and the person who complained about bathroom signs also stressed that Ahriman and Lucifer are not intrinsically "bad" but simply "forces that are around us" that we should strive to understand and "work with." ${ }_{138}$ Another Camphiller in Ireland said that she had left the UK to escape the bureaucracy, "but it was an illusion that it wasn't coming here." She came to see her task as "keeping the flame alight," even if just barely, until the time when Camphill's work "really shines" again. ${ }^{139}$ Inspections and regulations, one coworker told me, "have raised a lot of awareness. Of course it has made us improve in a lot of things." At the same time, they have brought "an extremely intellectual approach to people with learning disabilities, which is not the initial impulse of Camphill." You "medicalize the person" when you have to write up detailed plans about every aspect of their life, and "we have had to work very hard to counterbalance that with humanity and with just living together. Because the key ethos of Camphill is living together as equals with people, and not seeing them as the clients that we are managing and supporting."'

Some identify ways in which social care has moved in Camphill's direction. "The whole view of anthroposophy is to help us become more truly human," explained one coworker. The authorities support this when they insist on "reflective work, training opportunities and so on. ... [Care workers] are being encouraged to grow in their work and in their tasks. ... In Camphill, that one always has the opportunity to do many different tasks and develop many different possibilities in oneself." ${ }^{141}$ Another person said the Care Inspectorate was right to challenge Camphill to think more deeply about individual rights, both for villagers and for staff. "I think that's in keeping with what Rudolf Steiner would have wanted. Rudolf Steiner wasn't somebody who imposed anthroposophy on people. He said it has to come from the individuals really".142

The changes in social care have forced Camphill to think more consciously about its core identity. Is it, at heart, a network of schools and social care facilities that uses intentional community as a tool to provide the best possible care to 
persons with special needs? Or is at an intentional community movement that is especially committed to the full inclusion of all persons regardless of ability? For eighty years Camphill places have often defined themselves in both ways, depending on the context. A few have made definitive choices one way or the other: Camphill Village Kimberton Hills, for example, refuses to be licensed as a social care facility to underscore its identity as a community, while the Camphill Village Trust has abandoned incomesharing and lifesharing in order to accommodate the preferences of the social care establishment. At most other places, it is a lively topic of conversation. At Camphill School Aberdeen, for example, Jonny Mallam-Clarke told me that his house community regularly debated the issue, with different people taking different views. "I say, I live in an intentional community. It is also a school for children with special needs. Whereas some people would say, I work in a boarding school for children with special needs." He was sure Camphill's founders were on his side: "It was founded first and foremost as a community. . . . It was a community whose focus was work with children with special needs, but as one of the senior coworkers said to me, it could equally have been making shoes." ${ }^{143}$

The key choice, many Camphillers say, is between Camphill as "service provider" and Camphill as community. "The world wants to buy things, services, and we have to sell it," explained Christoph Hanni. To do that, you have "to be a good professional." But "it is not professionalism you need, you need to be you. When you meet, as you are, the other person, then something can happen. That is what Camphill is for." ${ }^{144}$ A government employee who has worked hard to help Camphill coworkers improve their relationships with social care authorities said that she often tells them that "if they wanted to continue to live here, then they had to turn more from being an intentional community to being a service provider. Because that is what the outside governing bodies were saying to them. You are a service provider." ${ }^{45}$ Another Camphiller suggested that Camphill's identity as a service provider was a useful "disguise," but not the true spiritual identity of the movement. "Disguise not in the sense of not being true," she clarified. "We do provide services to each other." So long as the deeper spiritual "idea is living, shining within me," it is fine to identify as a service provider. But she warned against confusing the disguise with the essence. ${ }^{146}$

A long-time coworker at Botton Village, Jonathan Reid, told me that his community confronted the choice between identifying as a community or a service provider in the 1990s, when their local authority asked them directly, "What is your core activity?" The person asking the question, he recalled, assumed that there was one right answer: "The answer should be social care provision, because you are actually asking for quite a lot of money to do that." But Jonathan had a different answer, inspired by Botton founder Peter Roth: "I felt very strongly that our community activity is not to have a core. . . Y You don't create something and say, this is it. You are constantly creating an empty space. That is why Peter was ... wildly enthusiastic about encouraging peripheral activities. Great idea to have 
a Waldorf school. Fantastic idea to have a eurythmy school. All these peripheral things which have been repeatedly questioned by the social care [authorities]... . feed back into the central space as unquantifiable richness. For life, for everybody's life. And especially for the life of people with a learning disability."147

Many refuse to blame the government for the changes in Camphill life, pointing out that Camphill could restore a more communal identity by refusing government funding. "We have lost our freedom," asserted Simon Beckett. "And that is our own doing. We still can live in the free spiritual life, as individuals carrying our own quality of life that each human being brings into the world with their karma, but we've lost the freedom to do that because we have become overburdened by the demands that the state puts upon us. And it begins with taking their money." ${ }^{148}$ Christoph Hanni added, "We like to preserve our comforts and we kill Camphill by it." 149 Tom Marx offered a milder self-criticism, suggesting that Camphill's difficulties in the face of the social care authorities stemmed from a lack of confidence. Instead of responding to inspections with fear, "we should offer alternatives. We are being asked by a Care Inspectorate who know nothing about who we are. And of course they are going to apply conventional models to us because that is what they know. It doesn't mean that they are unwilling to take what we know if we can show that it fulfills the regulation." 150

Some Camphillers who adamantly oppose the bureaucratization of their movement also hold out hope that Camphill may be on the cusp of a new developmental transition, in which it finally realizes its original vision of creating a community in which people of all abilities are truly equal. "As long as you are moving," mused one Camphiller, "even if it is downhill . . . and even if it is going into the muck, as long as you've got the speed behind it . . . the momentum can be the very thing that actually will lift you out again." You will come "out very different," but that is simply a challenge not to judge too quickly, lest "you actually become a bigger problem than the very thing you are criticizing." ${ }_{151}$ "We've been hiding very much under the old forms," said a coworker at Glencraig. But if they were to follow the logic of individualization all the way, they might be able to "bring community back to the forefront." A community that renounced the comforts of being a service provider would need to ask "how one supports each other" and "how does one actually generate the income one would need to live." But if Camphillers were to ask these honestly, they might "muster the last few ounces of chance to actually climb onto the next stage." 152

\section{DISABILITY RIGHTS}

Camphill's complex relationship with the social care establishment has a third partner: advocacy on behalf of persons with disabilities that stems not from the duties of caregivers but from the lived experiences of persons with disabilities themselves. Contemporary disability rights activism, as well as much scholarship in disability 
studies, centers on two claims that are encapsulated in pithy slogans. First, activists argue that persons with disabilities are harmed more by the structures and attitudes of society than by the physical symptoms of disability. Ours is, they say, a disabling society. Second, they insist that social change requires that persons with disabilities be democratically empowered to shape all the policies and institutions that in turn shape their lives. Here the rallying cry is, nothing about us without us. Both phrases emerged from the mobilization of people with physical disabilities in the 1970s, with Great Britain's Union of the Physically Impaired against Segregation playing a central role in crystallizing the "social model of disability," which distinguishes physical impairment from the harm caused by a disabling society. ${ }^{153}$

Camphillers have not always used the phrase disabling society, but that idea has been integral to the movement ever since Karl König identified the emphasis on measurable intelligence as one of the three "great errors." ${ }^{54}$ Such an emphasis, he clearly saw, prevents people with intellectual disabilities from sharing their unique gifts, and serves no useful purpose for the rest of society. The deep attachment that many nondisabled Camphillers feel for the movement stems from their realization that a disabling society ultimately harms everyone. A community built around the distinct needs of persons with intellectual disabilities, by contrast, is likely to provide everyone with the support we need to become our best selves.

Nevertheless, there is a significant difference between Camphill's response to the fact of a disabling society and that of most activists. While activists-especially those who framed such legislative remedies as the Americans with Disabilities Act (1990) and the British Disability Discrimination Act (1995) - often focus on removing specific societal obstacles to inclusion, Camphillers seek to build inclusive communities from the ground up. The distinction parallels the difference between the utopian socialist communities of the nineteenth century and the work of socialists who opted for union organizing, electoral politics, or violent revolution. As was the case for the different brands of socialists, there is much potential for competition and misunderstanding. Camphill can be faulted for serving only a small, often privileged subset of persons with disabilities, thus diverting energies that would better be directed toward society-wide transformation. As early as the 1970s, Camphill faced significant criticism from those who described Camphill places as "pleasant asylums" imposing a "benevolent segregation" on persons who should be empowered to integrate with the social mainstream. ${ }^{155}$ In 2004 the head of the British Council of Disabled People argued that while village-scale communities correctly "acknowledge that the rest of society doesn't yet include people with learning disabilities," their response is not to challenge that reality but to "go elsewhere, so as not to bother anybody."156 Conversely, Camphill could fault more mainstream activists for accepting piecemeal and partial solutions that leave many people with special needs feeling lonely and isolated. But there is also a potential for a mutually beneficial dialogue. To the extent that Camphill has achieved a form of community life that is not disabling and that is genuinely open to its neighbors, 
activists might use it as a model for larger-scale proposals. And to the extent that Camphill's reality still falls short of its aspiration, it could learn from the critical perspectives of activists at the cutting edge.

There are also important resonances between Camphill's vision and the insights of disability studies scholars who have sought to nuance the widely influential social model of disability. Many who accept the distinction between "impairment" and "disablement" nevertheless insist that the embodied experience of impairment can be as significant as socially imposed structures of disablement. ${ }^{157}$ Taking a cue from queer theory, some of these scholars suggest that it is not enough to remove barriers to inclusion; the larger goal is to "reverse the hegemony of the normal" and create space for the full expression of embodied difference and "new crip/ queer subjectivities."158 Camphill communities are adept at this sort of space making because they are designed from the ground up to foster the distinctive rhythms and lifeways of persons with learning difficulties. Scholars working at the intersection of queer studies and feminism also stress that "disability-like gender-is a concept that pervades all aspects of culture," extending far beyond the individual experiences of persons with disabilities. ${ }^{159}$ As complex intentional communities, Camphill places are able to bring a disability lens to their structuring of workplaces, homelife, and cultural activities. Camphill caregivers also draw inspiration from the work of disability scholars who are themselves parents of children with intellectual disabilities. Recognizing that no individual is an island, these scholars highlight the ways impairment and disablement impact the lives of families, friendship networks, and communities, and call for a culture of mutual caregiving akin to what is already happening at Camphill. ${ }^{160}$

The second slogan of disability rights activism, "nothing about us without us," expresses a complex and necessary challenge for Camphill. It is a necessary challenge because Camphill has not yet evolved structures that make people of all abilities truly equal participants in the deliberative processes that shape Camphill life. It is true that people with learning difficulties exert much indirect influence on Camphill life: coworkers and employees are continually observing the behavior of their companions and making adjustments intended solely to foster their wellbeing. This rarely happens in mainstream society. Yet this is not quite the point of the slogan. In the language of social threefolding, one might argue that Camphill's work with persons with disabilities has been exemplary in both the economic and cultural spheres, but significantly lacking in the rights sphere. That is, Camphill does a wonderful job of meeting students' and villagers' basic life needs, including their need for support, and it also allows them great freedom to express their creativity through artistic workshops and participation in cultural events. What is missing is simply the democratic participation that is the hallmark of the "middle sphere."

This is a complex challenge because intellectual disabilities, which often include communicative impairments, directly impact democratic participation in ways that vary widely from one person to another. Some people do not speak at all. 
Others communicate effectively, but experience severe anxiety when asked to make decisions that will impact others, or to grapple with such upsetting topics as sexual abuse. Still others may be adept at political participation, but may advocate for policies that are not well suited for the full range of persons with learning difficulties. All of these complexities could be used as an excuse, to argue that the slogan of "nothing about us without us" does not apply in cases of intellectual disability. A better response would be to recognize them as challenges to redoubled effort and commitment, and above all to a deeper dialogue with advocates from beyond Camphill.

That is in itself a challenge, because the self-advocacy movement itself is not yet fully inclusive of all persons with intellectual disabilities. It is wonderful when Camphillers with learning difficulties can join self-advocacy organizations in which they get to know other persons with similar disabilities who live in other, more "mainstream" settings. Such relationships can make it easier for the Camphillers to discern whether Camphill is indeed their preferred home, and to articulate ways to make it more suitable for them. But in fact many advocacy organizations are populated by persons who are quite different from those who live in Camphill. The principle of "nothing about us without us" was first articulated by activists with physical disabilities. One of the books introducing the slogan explicitly apologized for "the absence of people with mental and cognitive disabilities," despite the fact that they "combine to make up the largest disability 'category."' ${ }_{161}$ When persons with intellectual disabilities joined the conversation, people with autism who had strong written communication skills often were at the forefront.

The Autism Self-Advocacy Network, founded in 2006, is the advocacy organization with by far the greatest impact on current U.S. policy related to "care in the community" and other issues of social inclusion. Its website proudly displays the words "nothing about us without us"; it also reveals that at least five of the eight members of the organization's board of directors hold graduate degrees. ASAN has a strong commitment to cross-disability alliances and activism, and has articulated a pointed critique of the common distinction between "high" and "low" functioning individuals, since every person has a unique blend of functions they can perform easily and those with which they struggle. ${ }^{162}$ Nevertheless, its current structure reveals it is also on a journey toward full inclusion. There is no perfect group that Camphillers can simply join; rather, Camphillers should participate more fully in organizations like ASAN precisely in order to help them achieve their best aspirations.

Camphill's capacity to engage in that dialogue has been further limited by changes within Camphill that were themselves partly consequences of disability rights activism. As activists have urged that persons with learning difficulties be placed in the least restrictive setting possible, social care authorities have become much less willing to place persons with mild impairments at Camphill. Simply to survive, many Camphills have rebranded themselves (at least in their conversations 
with social care authorities) as specialized care facilities for profoundly disabled, usually nonverbal, individuals, or for people who have psychological, emotional, or behavioral challenges in addition to intellectual disabilities. Thus, the people who are most able to participate in the disability rights movement, as currently constructed, are unlikely to live at Camphill, while those who do live at Camphill would need a great deal of support merely to connect with the movement. All of this occurred at a time when many Camphill places were experiencing power struggles that diverted energies away from the practical empowerment of students and villagers.

The earliest reference to self-advocacy in Camphill's newsletter appears in a 2002 review of a book, Advocacy and Learning Disability, coedited by long-time Camphill ally and historian Robin Jackson. Neither the review nor the book is exclusively about self-advocacy, but give at least equal attention to "citizen advocacy," a concept first introduced by Wolf Wolfensberger. A citizen advocate, the review explains, is an unpaid and independent citizen who "creates a relationship with a person who is at risk of social exclusion and chooses one or several of many ways to understand, respond to, and represent that person's interests as if they were the advocate's own." The reviewer rightly notes that such practices are well established in Camphill, but gently prods the movement to embrace them even more fully. ${ }^{163}$ Implicitly, the review makes a point that is also borne out in the structures of many self-advocacy organizations for people with intellectual disabilities other than autism: for people with profound disabilities, self-advocacy often requires the partnership of strong citizen advocates. Most Down syndrome self-advocacy programs are not independent in the way ASAN is, but sponsored by umbrella organizations not exclusively directed by persons with disabilities. This has consistently been the style of self-advocacy in Camphill: it is initiated by coworkers or employees as a strategy for strengthening the rights sphere, rather than being created autonomously by persons with special needs themselves.

Camphill's hesitant embrace of self-advocacy often accompanied its effort to come to terms with legacies of sexual abuse. Like other organizations that work with vulnerable people, Camphill has never been entirely free of abuse. Sometimes this has been perpetrated by coworkers against individuals with special needs; sometimes it has been perpetrated by people with intellectual disabilities, either against other people with disabilities or against the children of coworkers. In some cases this occurred because people were not supported in finding healthy ways of expressing their sexual desires; in many cases it was exacerbated by Camphill traditions of placing unrelated adults and children in large family-style houses, and frequently moving them from house to house in ways that may have benefited some while compromising the freedom of others. Whether a coworker or a villager was the perpetrator, moreover, Camphill's practice of lifesharing made it difficult to protect others from harm without disrupting entire households, to say nothing of the lives of perpetrators who may themselves have needed care 
and support. In these cases, conversations about self-advocacy were confusingly tangled up with conversations about abuse, communal practices, and governance. That tangle might have been avoided had the movement proactively embraced practices of self-advocacy earlier.

Camphill Village Nottawasaga in Ontario was one place that enthusiastically embraced practices of self-advocacy in response to a painful episode of sexual abuse. In 2003 the Ontario government investigated multiple allegations of physical and sexual abuse perpetrated by coworkers, and ultimately mandated a restructuring of the board to exclude coworkers, the dismantling of the community's incomesharing structure, and the appointment of a nonresidential executive director. ${ }^{164}$ In the wake of these changes, coworker Chuck Kyd, then serving as president of the Camphill Association of North America, participated in the 2005 Camphill International Dialogue, where "self-advocacy" was identified as one of four program priorities within the "sphere of rights." 165 Soon thereafter the community hosted a conference where thirty-five visitors joined forty-five local residents to "explore the way self-advocacy is becoming manifest in our Camphill places." This was a time of deep learning from advocates beyond Camphill, as well as from the experiences of the participating communities. The conference began with a keynote by Judith Snow, a nationally prominent self-advocate from the community of people with physical disabilities. Another speaker, Judy Beeforth, addressed the theme of self-advocacy from the perspective of First Nations communities, and led the participants in creating a medicine wheel as a permanent part of the Nottawasaga property. After hearing from these outsiders, participants told their own communities' stories, often stressing collaboration with other organizations such as the "Speaking for Ourselves" group in Pennsylvania. They highlighted practices that allowed people with special needs to choose more individualized or independent living situations, or attain employment outside of Camphill. And they urged the movement to conduct similar events more frequently. ${ }^{166}$

Participants from both Camphill Nottawasaga and Camphill Soltane singled out Julia Wolfson as an inclusion consultant who helped them "bring about new attitudes and approaches to how we truly support our villagers and companions in a way that benefits all in our communities." ${ }^{167}$ Wolfson's influence in Camphill extends far beyond those two places. She has consulted widely with Camphill communities, especially in the wake of incidents of sexual abuse, and her work with Camphill communities in Norway, Botswana, and South Africa culminated in her 2013 dissertation, which explores "the role of inner empowerment in intentional personal and collective transformation in human service environments." ${ }^{168}$ Wolfson portrays Camphill places as idealistic communities that played an important role in the early empowerment of people with disabilities, but sometimes "slid into disjuncture" because of conflict, complacency, or a failure to engage sources of wisdom from beyond their walls. 
Wolfson's work draws on anthroposophical spiritual resources, placed in creative dialogue with insights from other spiritual and psychological traditions. On her website she lists Rudolf Steiner as one of four "wise teachers" who helped her "discover attitudes and ways of developing self and society as indivisible aspects of our evolving world." She credits Steiner in particular with setting "me on a lifelong adventure" by introducing her to practical initiatives like Camphill, and for insisting that an inner change of thinking is needed for outer social conditions to change. She quotes Steiner to this effect, as well as his claim that "spirit is never without matter, matter is never without spirit." 169 In her dissertation, she describes Steiner's position as "ethical individualism," suggesting that her understanding of inner empowerment flows directly from his ideals. ${ }^{170}$ She draws extensively on models of organizational transformation that are influenced by Steiner, such as the work of Otto Scharmer, and devotes an entire chapter to "Lessons from Physics" that uses the work of Arthur Zajonc, a physicist and a former general secretary of the Anthroposophical Society in America. She also cites the "process-oriented psychology" of Arnold Mindell, who blended elements of Jungian psychology and quantum physics in developing strategies for transformation.

Wolfson is controversial as well as influential among Camphillers. Supporters praise her for opening their eyes to the value of self-advocacy; while critics fault her for encouraging communities to abandon lifesharing and incomesharing, and to replace flat leadership structures with hierarchical ones. This raises an important question: are lifesharing and incomesharing at odds with the true empowerment of people with special needs? If so, this would be a powerful reason for Camphill to follow the path of "evolving beyond community", as a way of fully honoring its founding commitment to the human dignity of persons with special needs.

Wolfson does not make a categorical argument against the preservation of traditional Camphill practices. Instead, she highlights ways they can become dysfunctional. She notes, for example, that the revolving door of young coworkers, though it might seem to be enriching for all parties, can be "detrimental" to villagers who must deal with "relationships repeatedly being made and broken." She faults the unexamined assumption that unsalaried caregivers will be more "altruistic" than those who receive a salary, and notes that "in a shared economy it is more difficult for practitioners and leaders to leave when they want to, or to be asked to leave." She asserts that "traditional homes of up to 15 people or more are being replaced with smaller group homes and apartment-style living because fewer people-leaders, practitioners and people receiving services alike-want to live, eat, share bathrooms and their precious downtime with a big group of people they have not chosen to live with." ${ }^{171}$ All of these are fair points, but Wolfson could perhaps do more to help communities reconcile the demands of self-advocacy with the values inherent in traditional practices.

Traditional Camphillers who are committed to incomesharing and lifesharing might reasonably object that Wolfson is too attentive to the dangers inherent in 
those practices, and insufficiently alert to the pitfalls that accompany conventional nonprofit structures-especially since most Camphills that have abandoned the former have embraced the latter. Some might go further and suggest that the emphasis on individual choice and "rights" inherent both in her work and in the disability rights movement as a whole is one-sided. It seems reasonable to insist that people should not have to live with housemates they haven't chosen, but for many people the more important priority is not having to live alone. However much those Camphillers might object to the way Wolfson applies her principles, they must acknowledge that the principles themselves are faithful to Rudolf Steiner's vision, as articulated both in the "Sociological Law" and in the idea of the epoch of the consciousness soul. In the modern age, Steiner insisted, there is simply no way to bypass individual freedom, even in pursuit of a sense of community that transcends individualism. For this reason, both Wolfson and disability rights activists may be indispensable conversation partners if Camphill is to create a future that truly honors its past.

Disability rights activism underlies many of the changes in social care provision discussed in the previous section, above all the idea of "personalization" - that each person with a disability should be able to choose a unique package of support services to ensure their full inclusion in society as a whole. The question this raises for Camphill, and indeed for any intentional community that hopes to include all people regardless of ability, is this: is there an inherent tension between the ideal of community and the ideal of individual rights? Is community the antidote to a culture that makes a false god of individual rights, or is community actually a vehicle through which individual rights can be more fully realized? Given its roots in anthroposophy, Camphill ought to opt unequivocally for the latter answer. Yet this still leaves the complex task of applying that principle in particular cases.

One Botton coworker, Jonathan Reid, told a story that got at the dilemma. As his community was working to embrace the new culture of personalization, they brought in a consultant to do a workshop that included a "personalization exercise" designed for the villagers. Each person was supposed to fill out a diagram with concentric rings signifying "the relative importance of different people in their life." The first question posed to the villager was, who goes in the center? "And the learning-disabled person said, God. And the whole exercise went out the window, because they were supposed to say, Me. . . I see that gesture again and again and again, and it is a real inspiration for what a community needs to be." ${ }^{172}$ Jonathan's point was not to suggest that every community should have a theistic basis. It was, rather, that many people (and perhaps especially people with intellectual disabilities) do not experience themselves as the center of the world. That insight is wholly in keeping with the disability rights movement's insistence that people with disabilities should not be segregated into settings focused on their individual neediness, but should participate fully in the larger world. 
Camphill coworker Mischa Fekete insisted, should refuse the dichotomy of accepting or rejecting personalization as it is currently defined, and instead think deeply enough about it to arrive at its own unique evolutionary response. "Social research has shown," he explained, "that service provision where you have ... the workshop, the residential, the social, the health, everything wrapped together ... people with special needs are generally not supported or empowered as individuals to the same degree as in services where people get a little bit here, a little bit there, they access the services that they feel they need." Since Camphill "has always prided itself on [its] holistic way of service provision," this is a huge challenge. "Suddenly you have to find your own answer to that. ... We need to find our unique answers. ... Fifty years ago, Camphill was cutting edge. Now we are considered a dinosaur. ... It is challenging mostly because it challenges your value system." ${ }^{173}$

The pressures toward more individualized services for people with special needs run parallel to the desires of many coworkers to set the terms of their relationship with Camphill, and these in turn run parallel to trends in a wide range of intentional community movements, from kibbutzim to 1960s-era spiritual communities. Traditionalists may be right to worry that all of this spells the end of true community, especially if it means that each of Camphill's constituencies gets broken down into ever smaller subconstituencies: residential villagers versus sheltered workshop participants versus people with special needs who participate only in the cultural life; lifesharing coworkers versus lifesharing employees versus nonresidential employees versus members of the inner community who no longer live at Camphill. But perhaps all of this opens a door to a new sense of unity. What would it mean if Camphill were to abandon categories like "villager" and "coworker" and instead welcome new members as people, without regard to disability or desire for a residential placement? It might then ask each member, "What gifts do you have to offer our community? What support do you need? Do you want to live here full time? Do you want to manage your finances individually or as part of a group?" Is it possible for Camphill to honor each person's radical individuality, but still welcome them all in through the same doorway?

\section{CAMPHILL CRISES AND RENEWAL}

For much of the Camphill Movement, the twenty-first century has been a time of crisis. After sixty years of steady growth, dozens of Camphill places faced real threats to their survival. These crises gave new relevance to the apocryphal story that Karl König had predicted that Camphill would die out in the twentyfirst century. Very few Camphillers today take it for granted that their movement will still be thriving in fifty or a hundred years. Yet even in the face of crisis, few Camphill places have closed altogether. A few have left the Camphill Movement; 
several have transformed themselves in ways that have caused other Camphillers to question their authenticity; some have renewed their commitment to Camphill traditions; and still others are seeking radically new ways of being faithful to those traditions. In this concluding section, I will tell the story of three crises-one mostly resolved and two ongoing at the time of this writing (2020) - that may provide clues about Camphill's future.

These stories all unfolded against a background of movement-wide anxiety. By 2000 it was unremarkable for the Correspondence to publish articles implying that Camphill was dying. A typical piece claimed that long-term Camphillers had been "saying 'goodbye' to Camphill for the last decade," as the old movement gave way to an "Institutional Camphill" preoccupied with measurable outcomes and an "Institutional Community" composed of nostalgic memories. ${ }^{174}$ The back pages of the Correspondence also swelled, as more and more communities found they needed to advertise aggressively in order to fill vacant positions as teachers, workshop leaders, and house coordinators. Yet advertisements also showcased newly established communities, and predictions of disaster coexisted with optimistic reports about new strategies for fostering community and new dialogues within and beyond Camphill. The newsletter even included a hopeful message from someone who had experienced similar challenges in another communal context. A former brother in a Catholic religious order who had dissolved the connection between that order and its own disability services program affirmed that "Camphill still had the opportunity to hold together what he had broken apart: a life of vocation, of living together through Christian ideals, with a modern, innovative social service for people with special needs."175

The crisis for Camphill Vidaråsen came just before the millennium, and it had two parts. Beginning in 1996, former staff children began reporting incidents in which they had been sexually abused by individuals receiving care. Because the abuse had not been reported at the time it occurred, several of the perpetrators had moved from house to house or from one Camphill village to another, increasing the total number of victims. ${ }^{176}$ This revelation caused a great deal of "soul searching," recalled one person who lived at the village at the time. "What was it about the life here that made such things possible?" Was lifesharing "a completely naïve experiment" in which "the staff children had paid the price"? Around the same time, they also learned that one member of the community had misappropriated coworker funds, calling into question their "rather chaotic, flat organizational" structure in which many long-term coworkers served on a leadership team but no one had primary responsibility for management. The controversy coincided with a decline in applications from potential villagers. Many coworkers felt "knocked out" as they began implementing steps to help the persons who had been harmed and prevent future abuse. ${ }^{177}$ In 2005 the management team realized that they needed help, and over the next five years underwent a grueling transformation. They held forums for victims, issued apologies, created new policies, and worked 
with a series of consultants. The consultants prompted multiple short-lived reorganizations of leadership, with new leaders often struggling to overcome the anxieties and opposition of community members with divergent views of the situation. Among the consultants with whom they worked in these years was Julia Wolfson, who already had amassed significant experience helping Camphills adapt to the new culture of social care and disability rights. ${ }^{178}$

The village embraced many of the changes recommended by Wolfson. They created a more formal leadership structure, guaranteed all coworkers two days off each week (either Friday and Saturday or Sunday and Monday), created some residential separation between villagers and staff kids, and reduced the incomesharing aspects of their salary structure. Wolfson, one person recalled, advocated "a whole new methodology which would safeguard the villagers, safeguard the coworkers, safeguard the coworkers' children, and focus much more on developing the individual potential of the villagers first and foremost." But Wolfson and her allies took it for granted that this could be achieved most readily "if the integrated living structure would be disconnected and that coworkers would receive salaries and there would be more focus on professional training and competence and qualification for the coworkers." Some long-term coworkers felt disrespected by this: "They had given the best part of their lives on a voluntary basis, and now there was a focus on whether they were doing anything useful or not." But their response was fairly passive; they were still "shell-shocked" by the revelations of abuse. ${ }^{179}$

Another obstacle to the proposed reorganization of Vidaråsen was the other Norwegian Camphills, who had veto power over the proposal insofar as all of them were part of a single charity. They persuaded the board of the Camphill Village Trust to threaten Vidaråsen with exclusion if they followed through on the plan. Many parents of villagers also opposed the changes. They remembered that, when Norway shut down its social care institutions, Camphill had been allowed to survive because it "was recognized as being a kind of inside-out integration." From that perspective, putting "the total focus on the development of the villagers at the expense of everything else seemed to be a contradiction in terms." And so the parents insisted that lifesharing was necessary to ensure that their children would be treated not as "patients" but as "fellow citizens, as colleagues and friends."180

Tensions simmered until 2010, when Vidaråsen's coworkers rallied in opposition to a proposal to hire a single, employed manager "who would have the executive powers with regard to use of money, employment, all the things that had previously been in the hands of the carrying coworkers." ${ }^{181}$ At this point, the coworkers asked Will Browne, a long-standing coworker who was no longer living in the village, if he would be willing to take on a new leadership position. Will had been the one who had first disclosed the financial misconduct, as well as being involved in the response to the abuse. All this took a toll on his health. He had stepped away for most of the period when Wolfson was developing her report. This gave him the distance he needed to "get myself rejuvenated and ... excited about coming back 
and helping to pick up the pieces but also to learn from the mistakes we had made before and from the positive aspects of [Wolfson's] plan." He told the community that he was willing to come back as a leader only if he were elected to that role as part of a new leader group. Vidaråsen then empowered its village council, encompassing all long-term coworkers who chose to take part, to elect a leadership group of three members, with staggered terms of service. They also stipulated that members of the leadership group need not have any specifically managerial skills, such as the ability to construct a budget, understand legislation, or use a computer. Will insisted that employees be chosen to perform these tasks in a supporting capacity, so that "the only criterion" for holding decision-making power was "that one is seen to be carrying the values of the village." On these terms, he was elected to the leadership team three times, playing a curiously hybrid role as both an employee who performed many administrative tasks along with the other office employees and an elected community leader. The other two founding members of the leadership team were long term coworkers. At the time of this writing, Will was eagerly anticipating the end of his service on the leadership team and a fresh immersion in his old life as a coworker and architect. ${ }^{182}$

In the years after its leadership transition, Vidaråsen took multiple steps to rebuild the Camphill traditions of incomesharing and lifesharing in new ways. Despite external regulations that forced the community to pay differential salaries, the residential coworker group chose to pool their incomes and thus maintain a needs-based economy. They recruited a strong circle of millennial-generation coworkers, some of whom had grown up at Vidaråsen and most of whom were deeply committed to both incomesharing and lifesharing. The community has also attracted many younger villagers, giving them abundant opportunities to deepen the practices of self-advocacy that Wolfson had helped introduce. ${ }^{183}$

Vidaråsen's crisis experience demonstrates that it is possible for a Camphill community to preserve significant aspects of its communal heritage even in the wake of an abuse crisis and even when a thoughtful, well-constructed proposal for the abandonment of incomesharing and lifesharing is already on the table. It also shows that this is far from easy. Vidaråsen's coworkers alone could not have prevented more sweeping change. They had to rely on the support of a national network in which the other communities were all even more committed to Camphill traditions. Unlike Camphill places in the UK and Ireland, Vidaråsen did not experience any significant governmental pressure to change: Camphill is extraordinarily well-regarded in Norwegian society and has its own line item in the national budget. Compared to regulators in other countries, the Norwegian authorities have been very hands-off in their approach to Camphill, and on those occasions when they have been engaged they have generally allowed the Camphillers to set the criteria for their own regulation. The support of the parent community was also essential, and this support might not have been so unified if the victims of the reported abuse had been villagers rather than staff kids. 
Most other Camphills that have faced challenges similar to Vidaråsen's have responded differently. I got a vivid sense of this when I visited Botton Village in the summer of 2016, arriving with my family on the day of the Brexit vote. Botton, which is located in England's North Yorkshire Moors, holds a special place in the Camphill Movement. Until recently, it was the largest Camphill community in the world, with about three hundred residents-enough to merit its own post office, as well as a grocery store, church, Waldorf school, publishing house, four separate farms, training seminars for various anthroposophical practices, and a few successful businesses. It was the first Camphill place established as a village for adults rather than a school for children, and thus serves as the prototype for the adult villages that today constitute the majority of Camphill places worldwide. Botton's primary founder was Peter Roth, one of the original group of refugees who was known for his open-minded demeanor and mentorship of the baby boomers who came to Botton in the 1960 s and 1970s. The landscape of Great Britain is dotted with newer Camphill places that were founded by former Bottonites who were encouraged by Roth to take the Camphill vision to new places.

It is thus tragic but not especially surprising that Botton is the epicenter of the current struggle over the future of Camphill. For several years it was divided into hostile camps; after three years of mediation the two parties agreed to a legal settlement under which two autonomous communities would coexist on the Botton grounds. ${ }^{184}$ One party included the majority of long-term coworkers, who were committed to the traditional Camphill practices of lifesharing and work without salaries. The other side was led by managers hired by the overarching charity, the Camphill Village Trust, who believed that a more conventional employment structure was needed to preserve Camphill's access to state funding in a time of austerity. A few long-term coworkers took that side, believing that Camphill needed to evolve in order to survive. Villagers, short-term coworkers, and employees generally found themselves caught between the factions, with some villagers and their family members advocating publicly on behalf of preserving Camphill traditions.

It is not my intent to pass judgment on this conflict: I have not spent nearly enough time at Botton to do so in a responsible manner. Nor do I wish to draw an easy parallel between the conflict within Camphill and the conflict that was raging in British society at the time of my visit. In fact, a rare point of agreement between the two groups of Camphillers was that both were horrified by Brexit. Camphill is a cosmopolitan movement, with many long-term coworkers drawn from across the EU and beyond, while the managers hired by the Camphill Village Trust are the sort of educated professional inclined to sympathize with the EU and a globalizing vision. Yet Botton's neighbors in North Yorkshire voted in favor of Brexit by one of the highest margins in the UK.

And that was one underlying source of the problem. Botton, like so many intentional communities past and present, is a prosperous and cosmopolitan 
community of refugees tucked in an economically depressed rural area that has derived few benefits from globalization. The local authorities, including the authorities responsible for the care of persons with disabilities, are deeply distrustful of Camphill. Several years ago, the distrust became so intense that Camphill Village Trust imposed a moratorium on the placement of new villagers at Botton Village, causing it to lose its status as the largest Camphill in the world. All the controversial changes enacted by the Camphill Village Trust represent an attempt, thus far only partly successful, to regain the goodwill of the local authorities. And this is occurring in the context of the Conservative government's overall policy of budget austerity, which has generally been supported by Botton's North Yorkshire neighbors.

It is hard to blame the Camphill Village Trust for doing whatever it can to keep Botton afloat in a hostile environment-and it is also hard to blame Botton's neighbors for being at least somewhat suspicious of a community dominated by outsiders, many of them well educated with access to outside financial resources, on an estate that was given to them by the family of a prime minister!

The good news is that the crisis forced both sides to reach out to neighbors. As the community of long-term coworkers diminished, the Camphill Village Trust had to look locally for new employees, thus doing a tiny bit to reduce the chronic unemployment of the region. Some of the long-term coworkers who were forced out of Botton, meanwhile, moved only as far as the next town, where they now manage a health food store as the economic hub of their newly autonomous community within Botton. They forged activist alliances with neighbors who, with more access to the community than I have had, felt able to take sides in the conflict. These included the local Anglican priest and a local doctor who had first observed that Camphill villagers were much healthier than other persons with intellectual disabilities, and then that their health declined dramatically with the changes imposed by the Camphill Village Trust. It appeared to me that most of the neighbors who had actively taken sides took the side of the long-term coworkers, but this may have simply been because the long-term coworkers were the ones who mostly coordinated my visit. The neighbor-allies I met were from the professional class, and I have no reason to believe that their views were shared by the working class majority. The neighboring allies joined with the families of villagers to create Action for Botton, an activist organization that raised funds, media attention, and other resources on behalf of the long-time coworkers. ${ }^{185}$

The long-time coworkers' creative symbiosis with their neighbors has now flowered into the new Esk Valley Camphill Community. Esk Valley includes eighty people living in nineteen households within and beyond Botton Village. Some of them work in Botton workshops that are still managed by CVT. Others spend their days in offsite initiatives controlled by Esk Valley, among them the Health Food Shop in Danby and a garden provided by the Anglican parish. Esk Valley has also brought a new cohort of young coworkers to Botton, after many years in which the community experienced a steady pace of departures with almost no 
new arrivals. ${ }^{186}$ All of this depends on the general support of neighbors such as the shop's customers. It also requires an especially interesting partnership with Avalon Group, a local nonprofit that licenses most Esk Valley households under its "Shared Lives" framework. Shared Lives is a model of disability care that is usually applied to individual family households that care for one, two, or three persons with special needs. Like other "Shared Lives" organizations, Avalon Group is broadly committed to the ideal of "care in the community" and has no history of support for care based in intentional communities. It agreed to work with Esk Valley only after a protracted period of negotiation, and it does not feature its relationship with Esk Valley prominently on its website. ${ }^{187}$ Nevertheless, the fact that they've agreed to work with households that practice incomesharing and lifesharing means that they must now defend those practices to policymakers. It also means that the other households that they license may start to dialogue with and learn from the Camphill model.

The legal settlement in Botton has also resulted in a new model of relationship between the families of villagers and Camphill Village Trust. As part of the settlement, CVT agreed to extend membership in the charity to family members, "so that all CVT beneficiaries shall be entitled to have at least one relative/guardian/ family member as a CVT member. It also created a "Family Reference Group" on a trial basis at another of its village communities, Delrow. This "is not a decisionmaking body but does provide an avenue for 2-way information sharing between families and the charity." Once the trial is complete, similar bodies will be established at Botton and the Grange. CVT also agreed to bring one of the claimants onto its board immediately, and to allow another to fill the next vacancy designated for a family member. Though the consequences of these changes are uncertain, they have the potential to formalize the role of family members as an integral part of Camphill's social organism.

Perhaps the most exciting outcome of the Botton conflict is that the patterns of Camphill development-evolving beyond community and creative symbiosiswill now occur side by side. If the mutual animosity diminishes, each side will have abundant opportunities to learn from the other's experience; even if it remains, they will hardly be able to ignore one another's successes and failures. The results of their dialogue will doubtless reverberate through the rest of Camphill.

Another sort of dialogue is currently occurring among the Camphill communities in the United States. Though these communities have adopted widely variant approaches to incomesharing and lifesharing in the past decade, they have retained fairly open lines of conversation and connection through the Camphill Association of North America and the Camphill Foundation. Much of that dialogue today concerns the "Final Rule" for "Home and Community Based Services" that was issued by the Centers for Medicare and Medicaid Services in 2014. ${ }^{188}$ It defines what it means for services to be provided "in the community," as opposed to "in an institution," and thus to have automatic eligibility for Medicaid funding. 
It also contains provisions for waivers that would direct some funding to entities that do not fully comply with the rule.

The Final Rule, crafted in collaboration with the Autism Self-Advocacy Network and other disability rights organizations, requires any program receiving funds for services in the community to guarantee participants integration into the larger community, choice among a variety of settings, individual rights, and as much personal autonomy as possible. But it also contains a passage that describes what "in the community" is not, and this passage reads as if it were designed specifically to exclude programs like Camphill. "Farmsteads or disability-specific farm communities," "gated/secured community for people with disabilities," "residential schools," and "multiple settings co-located and operationally related," are all described as "typically having the effect of isolating people from the broader community," even if they are deliberately crafted to bring people with and without disabilities into community together. It appears that Camphill is not the primary intended target of this section: the crafters of the policy seem to have been reacting primarily to a trend among wealthy parents of persons with autism to create farms or communities intended to shelter their children from the stresses of mainstream society. But the effect is potentially devastating to Camphill, since even the practices that Camphill has been adopting in response to calls for mainstreaming, such as the creation of smaller communities in urban settings, still fall well outside the Final Rule's definition of "in the community." 189

The essential logic of the Final Rule is that an intentional community cannot be "in the community." This is why the Final Rule should be of interest to anyone who studies intentional communities, not just those interested in communities with a mission related to disability. The Final Rule might appear to be unique to Camphill's social care mission, not relevant for other sorts of intentional communities, but it echoes previous episodes in the history of communalism. Karl Marx's critique of "utopian socialism," for example, was in many ways a rejection of the refugee mentality found at Camphill: if some people are being treated unjustly by mainstream society, the proper response is to fight to change society, not to create places of shelter from it. In the 1840s, when Brook Farmers and other veterans of the Fourierist movement tried to take their communal ideals into the labor movement, they were sometimes received skeptically by working-class organizers who perceived them as bourgeois interlopers with lots of strange spiritual baggage. The hippie movement of the late 196os and 1970s was also characterized by tension with more political movements that insisted on direct confrontation with unjust social structures, rather than the creation of isolated communities. And there is the potential today for similar tensions between ecovillages and climate justice activists focused on direct confrontation with fossil fuel corporations, though for the most part this tension has not yet manifested.

Camphillers have responded to the Final Rule in diverse ways. Many Camphill places have reached out to other intentional communities affected by the Final Rule, forming coalitions such as Together for Choice and Coalition for Community 
Choice to advocate for the principle that all people with disabilities have a right "to live, work and thrive in a community or setting of their choice."190 (Because of lobbying efforts in the United States, it is possible that policy here will have changed significantly between the time of this book's writing and its publication.) It is hard to disagree with the principle of choice, yet implicit in it are significant challenges to Camphill. First is the challenge of discerning whether Camphill's residents with special needs have truly chosen to live there. Not all Camphillers use language to express their preferences. Among those who do use language, many have not experienced other residential options extensively enough to make an informed choice-just as people who live in urban group homes or private apartments may not have experienced Camphill-style community extensively enough to choose against it. Ordinarily, Camphill places require new residents to experience lengthy trial visits before making a final choice, and most have supported the departure of residents who discerned that they no longer wanted to live in Camphill. Yet one long-term Camphiller estimated that only five or six disabled residents of her community had made a truly free choice-adding that these people did much to sustain the cooperative spirit of the entire community. ${ }^{191}$

To the extent that Camphills support the choice making of their residents with disabilities, they may be challenged to make significant changes to their way of life. It could become clear that many villagers regard Camphill as a compromise that is valuable in some respects but far from ideal in others. Perhaps most residents of rural villages would rather live in town communities. It could become clear that Camphill is an appealing choice because of features that it does not share with "disability-specific" communities, such as the presence of large numbers of nondisabled persons who do not see themselves primarily as caregivers, but as farmers, artisans, or priests. Such a discovery would call into question the wisdom of aligning with the other communities in the policy arena. Conversely, it may be the case that many Camphillers with disabilities would prefer life in a disabilityspecific rather than lifesharing community.

The use of "choice" as a rallying cry for advocacy raises the question of how choice should be balanced with other values. Many disability rights advocates would argue that no one should be offered the "choice" to live in institutions with a track record of undermining human dignity, since such a choice is by definition not an informed choice. Camphillers would surely agree with respect to some institutional settings, however much they might object to applying the same argument to intentional communities in general. Camphillers also frequently appeal to the superior health outcomes experienced by people living in Camphill, even though it seems likely that these derive in part from community practices-healthy diets, active lifestyles, limited television-that are imposed uniformly on all residents rather than freely chosen by individuals.

Almost all Camphillers object to the Final Rule's underlying assumption that the only way to be "in community" is to be fully immersed in the residential and economic structures of the larger society, however inimical these may be 
to human thriving. To some, the Final Rule embodies the "there is no alternative" logic of neoliberal capitalism since the end of the Cold War. Others, more directly influenced by Rudolf Steiner, regard the checkbox criteria for discerning whether a particular program is or is not "in the community" as a classic example of "Ahrimanic" or excessively materialistic thinking. Steiner predicted that materialistic thinking would become ever more widespread with the approach of the incarnation of the demon Ahriman. Privately, some Camphillers use the word "Ahrimanic" to describe the logic of the Final Rule; publicly, they are more likely to couch their opposition in terms of the dangers of "bureaucracy."

Yet Camphillers also discern in the Final Rule a gesture of welcome from the larger society. At the heart of the Final Rule is the principle that persons with developmental disabilities should be able to live anywhere, work anywhere, and access any social resource that is available to persons without a disability. No Camphiller would reject this principle, yet in opposing the Final Rule they run the risk of being perceived as opposing it. A better strategy would be to embrace an open dialogue, seeking both to publicize the ways in which Camphill already embodies the ideals of the Final Rule and to change the aspects of its practice that run counter to those ideals. From an anthroposophical perspective, such a dialogue would help Camphill fulfill one of the central spiritual tasks of the present age, which is to engage creatively with the evolutionary trend toward greater materialism and individualism.

What makes this moment in Camphill history especially challenging is that both interpretations of the Final Rule may well be correct: it may embody a materialistic worldview that is inimical to genuine community and be a sign that the larger society is now ready to embrace both persons with special needs and the communal ideals of Camphill. That both/and interpretation is usually the dominant approach when Camphillers gather as a group to discuss the Final Rule. They are genuinely alarmed about the Final Rule, and eager to work creatively with the Rule and, especially, with the disability self-advocacy groups that had helped craft it. Similarly, they are eager to foster new partnerships with other intentional communities engaged in social care, but also aware that some of those communities may embody patterns of paternalism or institutionalization that should not be defended. What's more, Camphillers are willing and able to think about the Final Rule both in publicly accessible terms and in relation to the anthroposophical spirituality that has accompanied Camphill throughout its history. For me, that is perhaps the most hopeful sign about Camphill's future. 